\title{
Göçün Güvenlikleştirilmesi Bağlamında Bulgaristan'ın Suriyeli Göçmenlere Yönelik Politikası
}

\author{
Bulgaria's Policy towards Syrian Migrants \\ in the Context of Securitization of Migration
}

\section{Kader ÖZLEM*}

$\ddot{0} z$

Göç-güvenlik ilişkisine dair yapılan çalışmalarda, Soğuk Savaş sonrası dönemde uluslararası göç olgusunun bir güvenlik tehdidi olarak algılanmaya başlamasıyla birlikte artış yaşanmıştır. Uluslararası İlişkiler Teorileri bağlamında düşünecek olursak, gelişstirdiği eleştirel güvenlik perspektifiyle Kopenhag Okulu'nun özellikle göç olgusunun nasıl güvenlikleştirildiği konusunu anlama bakımından önemli katkaları olmuştur. Çalışmada bu perspektiften hareketle Suriye İç Savaşı'nın başlamasını takip eden dönemde Bulgaristan'ın göç ve güvenlik politikaları arasındaki ilişki analiz edilecektir. Bilindiği üzere savaşın başlamasını müteakiben pek çok Suriyeli Türkiye üzerinden Batı Avrupa ülkelerine göç etmeye başlamıştır. Bir geçiş ülkesi olarak Bulgaristan, daha önce hiç yaşamadığı bu yoğun göç dalgasını hızla güvenlikleştirerek bir güvenlik tehdidi olarak inşsa etmiştir. Çalışmanin temel amact, Bulgaristan'in Suriyeli göçmenlere dönük politikalarını ve bu güvenlikleştirme (securitization) sürecini çok boyutlu bir şekilde analiz etmektir.

Anahtar Kelimeler: Bulgaristan, Suriyeli Göçmenler, Uluslararası Göç, Güvenlik, Güvenlikleştirme.

\footnotetext{
* Dr. Öğr. Üyesi, Bursa Uludağ Üniversitesi İktisadi ve İdari Bilimler Fakültesi Uluslararası İlişkiler Bölümü, ORCID No: 0000-0003-4780-2118, E-posta: kaderozlem@uludag.edu.tr.

\section{5}

Güvenlik Stratejileri

Cilt: 16

Say1: 35 
556

Güvenlik Stratejileri

Cilt: 16

Sayı: 35

\section{Abstract}

The studies on 'security-migration' nexus has increased with being perceived as a security threat of the international migrations in the postCold War period. The Copenhagen School as a critical security approach in the context of International Relations Theories has contributed to understand the subject how migrations have been securitized specifically. From this point of view, the relation between migration and security policies of Bulgaria is going to be analyzed during period of Syrian Civil War. As known, following the beginning of Syrian Civil War plenty of Syrians have started to migrate towards Western European countries through Turkey. Bulgaria as a transit country has constructed this migration wave that she has never seen before as a security threat by securitizing it rapidly. The main scope of this study is to analyze Bulgaria's policies towards Syrian migrants and this securitization process from the multidimensional perspective.

Keywords: Bulgaria, Syrian Migrants, International Migration, Security, Securitization.

\section{Giriş}

Uluslararası göç ve nüfus hareketleri Soğuk Savaş sonrası dönemde önemli bir güvenlik konusu olarak ön plana çıkmıştır. Buna mukabil, Uluslararası İlişkiler disiplinin yerleşik kuramlarının bu yeni güvenlik tehdidini açıklamakta zorlandığı görülür. Ana-akım teorilerin devlet merkezli bakış açıları ile eleştirel kuramların meseleyi salt kimlik ve kültür ekseninde tanımlama çabaları göç olgusunun eksik kavranmasina neden olmaktadır. Oysa devletlerin ve hatta uluslararas1 sistemin tarihsel süreç içerisindeki şekillenişlerinde son derece etkili bir unsur olan uluslararası göçlerin yadsınamaz bir olgu olarak disiplinin teorik tartışmalarında ele alınmış olması beklenirdi. Göç konusunda bütüncül bir yaklaşım sunmamakla birlikte Kopenhag Okulu, özellikle güvenlik olgusunu derinleştiren ve genişleten sektörel güvenlik anlayışı ve söylem yoluyla tehditlerin nasıl inşa edildiğini gösteren güvenlikleştirme kavramıyla göç çalışmalarına yeni bir ivme kazandırmıştır.

Güvenliğin çok boyutlu bir şekilde ele alınması gerektiğini göstermesi bakımından uluslararası göç olgusu ve özellikle Suriyeli 
göçmenler meselesi ayrı bir önem taşımaktadır. Bilindiği üzere Suriye İç Savaşı'nın başladığı 15 Mart 2011 sonrasında can ve mal güvenliği kaygisıyla milyonlarca Suriyeli ülkelerini terk etmiş ve bu göçmenlerden yaklaşık 3,5 milyonu komşu ülke Türkiye'ye gitmiştir. Suriyeli göçmenlerin Türkiye üzerinden Batı Avrupa ülkelerine göç etme istekleri ise özellikle Bulgaristan'1 derinden kaygılandırmaktadır. Suriyeli göçmenleri ulusal güvenliğine dönük bir tehdit olarak algılayan Bulgaristan, bu tehdidi bertaraf edebilmek için bir yandan aktif bir diplomasi yürütürken diğer yandan ulusal düzeyde tedbirler alma yoluna gitmiştir. Bu bağlamda Sofya yönetimi, olası bir kitlesel göçün yol açabileceği siyasi, askerî, ekonomik ve toplumsal olumsuzluklarla baş edebilmek için Avrupa Birliği (AB)'nin soruna daha fazla yoğunlaşmasını istemiştir. Yine benzer şekilde, Bulgaristan'ın bu tehdidi ortadan kaldırabilmek ya da etkilerini minimum düzeyde tutabilmek maksadıyla Türkiye ile de yoğun bir şekilde iş birliği yapmaya çalıştığı görülür.

Elbette Bulgaristan'ın söz konusu tehditle mücadele amaciyla ulusal düzlemde de birçok tedbir aldığ 1 görülür. Bu maksatla alınan tedbirlerin bir bölümü ise Bulgar kamuoyunun dikkatini göç meselesine çekmek ve atılacak adımlara daha geniş bir kamuoyu desteği sağlamak amacı taşıdığı söylenebilir. Bu nedenle makalenin kuramsal çerçevesini eleştirel güvenlik çalışmalarında önemli bir yere sahip olan Kopenhag Okulu ve onun kilit kavramlarından biri olan güvenlikleştirme oluşturmaktadır. Çalışmada yöntem olarak ise güvenlikleştirme en nihayetinde bir söz-edim (speach act) faaliyeti olduğu için söylem analizi seçilmiştir. Çalışmada yanıtı aranan soruları ise şu şekilde sıralamak mümkündür:

- Göç olgusunun güvenlikleştirilmesi nasıl gerçekleşmektedir?

- Göç konusu Bulgaristan'ın Ulusal Güvenlik Stratejisi Belgeleri'nde nasıl ele alınmaktadır?

- Suriyeli göçmenler sorununun yönetimi konusunda Bulgaristan nasıl bir politika izlemiştir?

- Sektörel güvenlik anlayışı perspektifinden Suriyeli göçmenlerin Bulgaristan'ın güvenliğe yönelik oluşturduğu riskler ve tehditler nelerdir? 


\section{8}

Güvenlik Stratejileri

Cilt: 16

Sayı: 35

\section{Kopenhag Okulu'nun Güvenlik Yaklaşımı ve Göçün Güvenlikleştirilmesi Meselesi}

Yukarıda da değinildiği üzere, Uluslararası İlişkiler kuramları uluslararası göç olgusunu güvenlikle bir arada açıklama hususunda yetersiz kalmaktadırlar. Bilindiği gibi ana-akım teorilerin Uluslararası İlişkiler'in sosyal boyutunu göz ardı ettiğine dair itirazlar 1980'li yıllarla birlikte disiplin içerisinde yeni bazı teorik perspektiflerin geliştirilmesine yol açmıştır. Özellikle epistemolojik düzlemde yürütülen tartışmalar disiplin içerisinde farklı kuramların ortaya çıkmasıyla sonuçlanmıştır. Disiplininin Amerikalılaşan görüntüsü ve buna yönelik Avrupa'dan yükselen itirazlar aynı zamanda yeni ve eleştirel bir güvenlik anlayışının gelişmesine de yol açmıştır. Soğuk Savaş döneminin sona ermesiyse 1990'l y yllarla birlikte bu yeni güvenlik anlayışının daha da gelişmesini mümkün kılan bir uluslararası ortam yaratmıştır.

Sistemik değişimle birlikte artık güvenliğin salt askerî-teknik boyutuna değil ama aynı zamanda siyasi, ekonomik, toplumsal ve hatta çevresel boyutlarına da eğilmek mümkün olmuştur. Bu bağlamda Aberystwyth, Paris ve Kopenhag gibi yeni güvenlik anlayışını temsil eden Okullar ortaya çıkmıştır. ${ }^{1}$ Bunlar içerisinden özellikle Kopenhag Okulu güvenlik anlayışının yeniden tanımlanmasını mümkün kılan perspektifiyle disiplin literatürünü zenginleştirmiştir. Zira güvenlik çalışmalarını salt devlet merkezli bir anlayışla ele almayan Kopenhag Okulu, 1990'lı yıllarla birlikte disipline dâhil olan uluslararası göç olgusunun yanı sıra uluslararası suç örgütleri, bireysel ve çevresel güvenlik, terör örgütleri ve etnik gruplar gibi unsurların da güvenlik çalışmalarına dâhil edilmesini mümkün kılmıştır. Dolayısıyla Kopenhag Okulu mensupları bir yandan geleneksel güvenlik anlayışını derinleştirmesini sağlarken, öte yandan güvenlik konularını çeşitlendirerek güvenliğin kapsamını genişletmişlerdir. Diğer bir deyişle sadece devletler ve uluslararası sistem değil, bireyler ve devlet dışı aktörler de güvenliğin

\footnotetext{
${ }^{1}$ R.B. J. Walker, "Security, Critique and Europe", Security Dialogue, Vol. 38, No. 1,
} March 2007, 95-103, p. 97. 
çalışma alanına dâhil edilmiştir. Bu mikro perspektif, güvenliğe yönelik evrensel bakış açısını ortadan kaldırmamış, aksine analitik düzlemin genişlemesini mümkün kılmıştır. Bu durum güvenlik çalışmalarında yatay ve dikey yönde bir genişlemeye işaret etmektedir.

İnşacı kuramın temel varsayımlarıyla benzeşen bir perspektiften hareketle güvenlik çalışmalarına yeni bir bakış açısı kazandıran Kopenhag Okulu ve onun önde gelen temsilcilerinden Barry Buzan, Ole Waever ve Jaap de Wilde gibi isimler 1990'lı yıllarda yaptıkları çalışmalarla kilit bir kavram olarak güvenlikleştirmeyi Uluslararası İlişkiler literatürüne kazandırmışlardır. ${ }^{2}$ Kimlik, toplum, söylem gibi kavramlarla Westphalian sistem kurgusuna ve ABD merkezli güvenlik anlayışlarına itiraz eden Okul, Batı dışındaki ülkeleri de kendine has özelliklerini dikkate alarak birer analiz birimi haline getirmeye çalışmıştır. ${ }^{3}$ Ayrıca Kopenhag Okulu'nu güvenlik çalışmaları içerisinde popüler hale getiren husus üç merkezî kavram üzerine yoğunlaşmış olan çalışmalardır. Bunlar; Waever'ın geliştirdiği "güvenlikleştirme" ve "güvenlik-dış1laştırma" (de-securitization), Buzan'ın ortaya attığı sektörel güvenlik anlayışı çerçevesinde ön plana çıkan "toplumsal güvenlik" ve bölgesel güvenlik kompleksi yaklaşımın merkezinde yer alan "güvenlik kompleksleri" kavramlarıdır. ${ }^{4}$

Güvenlikleştirme kavramının analizine geçmeden önce Barry Buzan tarafından ileri sürülen ve geleneksel güvenlik anlayışının yetersizliğine ilişkin görüşlerini kısaca ele almak gerekir. Buzan'a göre birey, devlet ve uluslararası sistem olmak üzere üç düzeyde de analiz edilmesi gereken güvenliğin ${ }^{5}$ en baskın aktörü şüphesiz yine devlettir.

\footnotetext{
${ }^{2}$ Nazif Mandacı ve Gökay Özerim, "Uluslararası Göçlerin Bir Güvenlik Konusuna Dönüşümü: Avrupa'da Radikal Sağ Partiler ve Göçün Güvenlikleştirilmesi”, Uluslararası İlişkiler, Cilt 10, Sayı 39, Güz 2013, 105-130, s. 107.

${ }^{3}$ Claire Wilkinson, "The Copenhagen School on Tour in Kyrgyzstan: Is Securitization Theory Useable Outside Europe?", Security Dialogue, Vol. 38, No. 1, March 2007, 525, p. 22.

${ }^{4}$ Wilkinson, ibid, p. 8.

${ }^{5}$ Barry Buzan, People, States, and Fear The National Security Problem in International Relations, Wheatsheaf, Brighton, 1983, pp. 245-247.
}

\section{9}

Güvenlik Stratejileri

Cilt: 16

Say1: 35 

Bununla birlikte Buzan güvenliği beş farklı sektöre ayırarak, klasik güvenlik anlayışını genişletmiştir. Bu sektörler, askerî güvenlik, politik güvenlik, toplumsal güvenlik, ekonomik güvenlik ve çevresel güvenlik şeklinde sıralanmaktadır. ${ }^{6}$ Buzan'ın söz konusu yaklaşımında her ne kadar aktör olarak devlet ve konu itibarıyla askerî güvenlik önemini korusa da politik, ekonomik, çevresel ve toplumsal alanlarda beliren yeni tehdit unsurları artık güvenliğin daha kümülatif bir perspektifle ele alınmasını zorunlu kılmaktadır. Buzan'a göre devletlerin ve toplumların uluslararası sistem içerisinde öz kimliklerini ve işlevsel birlikteliklerini sürdürebilme kabiliyetleri güvenlikleriyle doğrudan alakalıdır. ${ }^{7}$

Kopenhag Okulu ile özdeşleşen "güvenlikleştirme" kavramı ise Ole Waever tarafindan ileri sürülmüss olup temel olarak söz-edim faaliyetleriyle tehditlerin nasıl inşa edildiklerini ortaya koymakta ve klasik güvenlik alana girmeyen pek çok konunun içselleştirilmesini mümkün kılmaktadır. Diğer bir deyişle askerî güvenlik alanı dışındaki konuların da güvenliğin bir unsuru haline getirilmesi bu sayede mümkün olmaktadır. Waever, güvenlikleştirme kavramıyla birlikte ileri sürdüğü "güvenlik-dışlaştırma" ise önceden tehdit olarak algılanan ve güvenlikleştirilen konunun artık tehdit olmaktan çıkması durumunu ifade etmektedir.

En basit ifadesiyle güvenlikleştirme, karar vericinin önem atfettiği bir meseleyi diğer meselelerin üzerinde bir yere taşıyarak onu öncelikli hale getirmesidir. İlgili konunun güvenlikleştirilebilmesi için doğrudan varoluşsal bir tehdit olarak sunulması önemlidir. ${ }^{8} \mathrm{Ne}$ var ki konuyu güvenlikleştiren aktör, bununla yetinmeyip söylemlerinin dinleyiciler üzerinde ikna edici olmasını da temin etmelidir. Zira ikna edicilik özelliği taşımayan konuşmalar sadece güvenlikleştirme hareketi olarak kalırken, nihai aşamada başarılı bir güvenlikleştirme işlemi

\footnotetext{
${ }^{6}$ Buzan, ibid, pp. 75-83.

${ }^{7}$ Bilal Karabulut, Güvenlik - Küreselleşme Sürecinde Güvenliği Yeniden Düşünmek, Barış Kitabevi, Ankara, 2011, s. 70.

${ }^{8}$ Barry Buzan, Ole Waever ve Jaap de Wilde, Security: A New Framework for Anaylsis, Lynne Rienner Publishers, London, 1998, p. 24.
} 
söylemin dinleyiciler yani kamuoyu tarafindan kabul edilmesiyle gerçekleşmektedir. ${ }^{9}$ Referans nesnesi, güvenlikleştiren aktör ve dinleyiciler şeklinde ifade edebileceğimiz üç unsur ${ }^{10}$ etrafinda işleyen bir süreçte herhangi bir konu varoluşsal bir tehdit olarak sunulur ve bunun kamuoyu tarafından benimsenmesiyle güvenlikleștirme sağlanır. Böylelikle karar vericiler açısından olağan zamanlarda imkânsız gibi görünen kararların alınabilmesi mümkün olmaktadır. Kısacası güvenlikleştirme olağanüstü önlemlerin alınmasının önünü açarken siyasetin de olağan kuralların dişına çıkmasını ve hatta onları askıya almasını sağlayabilmektedir. Elbette bu birtakım riskleri de bünyesinde barındırır. Örneğin demokrasinin aksaması ya da demokratik kuralların işleyişinin ertelenmesi bu bağlamda akla gelebilecek olasılıklardır. ${ }^{11}$

Görüldüğü üzere güvenlikleştirme aslında herhangi bir dişsal unsura ihtiyaç duyulmadan da işleyebilecek bir süreçtir. Bununla birlikte söylemlerin güvenlikleştirmede oynadığı belirleyici rol, siyasi elitleri ön plana çıkarmaktadır. Bu nedenle siyasi elitlerin söylemlerinin analizi, güvenlikleştirme açısından başlıca yöntem olarak karşımıza çıkmaktadır. ${ }^{12}$ Diğer bir deyişle söylem analizleri güvenlikleştirme çalışmalarının olmazsa olmaz unsurlarındandır. Sosyal İnşacı kuramın önde gelen temsilcilerinden biri olan Nicholas Onuf'un deyimiyle "Söylemek yapmaktır. Konuşmak hiç şüphesiz dünyanın ne olduğunun düzenlenmesi hakkında gidebileceğimiz en önemli yoldur". ${ }^{13}$ Onuf'a göre konuşma faaliyetleri, yani söylemler birilerini harekete geçirmeye ve başarmaya odaklanan işlevsel birer mekanizma görevi görmektedir. ${ }^{14}$ Zira söylemler sistemli bir şekilde bilgileri düzenler ve neyin söylenip

\footnotetext{
${ }^{9}$ Buzan,Waever ve Wilde, ibid, p. 25.

${ }^{10}$ Holger Stritzel, "Towards a Theory of Securitization: Copenhagen and Beyond", European Journal of International Relations, Vol. 13, No. 3, 357-383, p. 362.

${ }^{11}$ Stritzel, ibid, p. 362.

${ }^{12}$ Buzan, Waever and Wilde, ibid, p. 25.

${ }^{13}$ Nicholas Onuf, "Constructivism: A User's Manuel", International Relations in a Constructed World, (ed. Vendulka Kubalkova-Nicholas Onuf-Paul Kowert, M.E. Sharpe, New York, 1998, 58-78, p. 59.

${ }^{14}$ Onuf, agm, p. 66.
}

561

Güvenlik Stratejileri

Cilt: 16

Say1: 35 
562

Güvenlik Stratejileri

Cilt: 16

Sayı: 35 söylenemeyeceğini sınırlandırarak, kendi bağlamları içerisinde kritik bir görev üstlenirler.

Yukarıda da ifade edildiği üzere uluslararası göç olgusu özellikle Soğuk Savaş sonrası dönemde ortaya çıkan yeni risk ve tehdit unsurları arasında kendisine önemli bir yer edinmiş durumdadır. $\mathrm{Bu}$ yönüyle uluslararası göçün artık bir güvenlik tehdidi olarak tanımlandığı da söylenebilir. Dolayısıyla göç olgusu günümüz dünyasında güvenlikleştirme süreçlerinin de önemli bir bileşeni haline gelmiştir. Buzan'ın çerçevesini çizdiği ve birbirleriyle doğrudan bağlantılı olarak kurguladığı güvenlik sektörleri içerisinde uluslararası göçler daha ziyade toplumsal güvenliğin ilgi alanına girmektedir. Kimlik ve kültür gibi kavramlarla doğrudan ilgili olması ve yol açtığı demografik sorunlar ya da yeni ötekilerin yaratılmasını mümkün kılması nedeniyle göç olgusu toplumsal güvenliğe doğrudan etki edebilmektedir. Bu nedenle göçün sıklıkla ve doğrudan karar vericiler eliyle güvenlikleştirildiği görülür.

Toplumsal güvenlik temel olarak bir kimliğin algilanan bir tehdide karşı savunulması veya bir nevi kimliğin güvenliğinin sağlanması olarak ifade edilebilir. ${ }^{15}$ Toplumsal güvenliğin kimlik üzerinden inşası referans alındığında, uluslararası göçlerin ulusal kimliğe tehdit olarak sunuldukları görülmektedir. ${ }^{16}$ Waever bu tehdidi, "X halk1 $\mathrm{Y}$ halkı tarafından istila edilmekte veya o halk yüzünden özelliklerini kaybetmektedir; $X$ topluluğu eskisi gibi var olmayacaktır, çünkü nüfusu diğerleri oluşturacaktır. $\mathrm{X}$ kimliği, nüfusun yapısındaki değişim nedeniyle (Çinlilerin Tibet'e, Rusların Letonya'ya göçü gibi) farklılaşmaktadır"17 biçiminde aktarmaktadır. Söz konusu ifadelerde geçen "istila", "kimlik", "diğerleri" gibi anahtar sözcükler aslında bu kavramların göç literatüründe de ayrıcalıklı bir yere sahip olduğunu göstermektedir. ${ }^{18}$ Yine Waever'ın

${ }^{15}$ Ole Waever, “Toplumsal Güvenliğin Değișen Gündemi”, Uluslararası İlişkiler, Cilt: 5, Say1: 18 (Yaz 2008), 151-178, pp. 153-155.

${ }^{16}$ Barry Buzan ve Lene Hansen, The Evolution of International Security Studies, Cambridge University Press, Cambridge, 2009, p. 231.

${ }^{17}$ Waever, 2008, ibid, p. 158.

${ }^{18}$ Mandac1-Özerim, agm, s. 108. 
"yatay rekabet" olarak tanımladığı ve "X halkının orada hâlâ yaşamaya devam etmesine rağmen komşu kültür olarak Y'nin kültürel ve dil açısından öne çıkan etkileri nedeniyle yaşam şekillerinin değişeceği" biçimindeki algı da göçün toplumsal güvenlikle bağıntısını ortaya koyan bir diğer husustur. ${ }^{19}$ Dolayısıyla göçmenlerin veya göçmenler bazında rakip olarak algılanan diğer kimliklerin güvenlikleştirilmesi hususu, ortak kimliğe sahip olanların kendi kimliklerini nasıl oluşturdukları ve ne şekilde devam ettirecekleri konusuna bağlı olmaktadır. ${ }^{20}$

Diğer taraftan göç edilen veya edilecek olan ülkede söz konusu göçmen kitleye yönelik bakış açısı veya halkın içinde bulunduğu psikolojik şartlar da göçün güvenlikleştirilmesi sürecinde önemli rol oynayabilmektedir. Örneğin 11 Eylül 2001 saldırıları sonrasında Amerika Birleşik Devletleri (ABD) kamuoyunda veya Madrid (2004) ve Londra (2005) saldırılarının ardından Avrupa' daki halkların zihnindeki Müslüman algısındaki olumsuzluklar derinleşmiş̧ir. Bu nedenle ilgili coğrafyalarda özellikle Müslümanların göçüne sıcak bakılmadığı söylenebilir. Bu durum Batı'da siyasi elitlerin göç olgusunu güvenlikleştirmesini kolaylaştırmıştır. Konumuz bağlamında somutlaştırmak gerekirse Bulgaristan'ın Türkiye üzerinden gelebilecek Suriyeli göçmenler sorununu güvenlikleştirmesi de bu şekilde olmuştur. Aşağıda detaylı inceleneceği üzere modern Bulgar kimliğinin inşasında öteki Osmanlı imgesi bağlamında Türkler ve Müslümanlar olmuştur. Dolayısıyla gerek Suriyeli göçmenlerin Müslüman kimlikleri gerek Bulgaristan'a getirecekleri ekonomik maliyetler Bulgar siyasi elitinin kamuoyu/dinleyiciler üzerinde daha ikna edici olabilmesini ve meseleyi daha rahat güvenlikleştirebilmesini sağlamaktadır.

\section{Suriyeli Göçmenler Meselesinin Gelişim Süreci ve Bulgaristan'ın Ulusal Güvenlik Stratejisi}

Orta Doğu'da yaşanan Arap Baharı'na bağlı olarak 15 Mart 2011 tarihinde Suriye'de halkın başlattığı gösteriler Nisan ayında ülke geneline yayılırken, göstericilerin üzerine rejim güçlerince ateş açılması

\footnotetext{
${ }^{19}$ Waever, 2008, ibid, p. 158.

${ }^{20}$ Buzan, Waever and Wilde, ibid, p. 23.
}

\section{3}

Güvenlik Stratejileri

Cilt: 16

Say1: 35 
564

Güvenlik Stratejileri

Cilt: 16

Sayı: 35

sonucunda yüzlerce kişi öldürülmüş ve binlerce kişi de tutuklanmıştır. ${ }^{21}$ 2011 yılının ilk yarısında yaşanan bu gelişmeler Suriye İç Savaşı'nın başlangıcını oluşturmakla birlikte, bu çalışmanın kaleme alındığı Mart 2020 itibarıyla Suriye'de iç savaş dokuzuncu yılını doldurmuştur. Bu süre zarfında ülkedeki yerel aktörlerin yanı sıra bölgesel ve küresel güçlerin de denkleme dâhil olması değişen güç dengeleri bağlamında Suriye İç Savaşı'nın farklı bir boyuta evrilmesine ve kronik hale gelmesine yol açmıştır. dokuz yıllık iç savaş boyunca Mart 2020 itibarıyla 586.100 kişi hayatını kaybetmiş, iki milyondan fazla Suriyeli sivil de yaralanmıştır. ${ }^{22}$

Suriye İç Savaşı'nın konumuzla ilgili olan kısmı ise bu dönemde yaklaşı 5,5 milyon kişinin göçmen (mülteci) ${ }^{23}$ durumuna düşmesi ve yaklaşık 12 milyon kişinin de yerlerinden edilmesidir. Birleşmiş Milletler Mülteciler Yüksek Komiserliği (The United Nations High Commissioner for Refugees)'nin verilerine göre bu göçmenlerin Nisan 2020 itibarıyla \%65'lik oranına karşıllk gelen 3.583.584 kişisi Türkiye'de bulunmaktadır. ${ }^{24}$ Türkiye'nin Suriye ile sınırında yer alan illerin

${ }^{21}$ Human Rights Watch, "We've Never Seen Such Horror - Crimes against Humanity by Syrian Security Forces", June 2011, p. 1.

${ }^{22}$ Syrian Observatory for Human Rights, "Syrian Revolution Nine Years on: 586,100 Persons Killed and Millions of Syrians Displaced and Injured", 15.03.2020, http://www.syriahr.com/en/?p=157193, (Erişim tarihi: 18.03.2020).

${ }^{23} 1951$ Cenevre Sözleşmesi’ni coğrafi sınırlandırma getirerek imzalayan Türkiye, Avrupa Konseyi üyesi ülkeler dışından gelen ve iltica etmek isteyen kişilere yönelik geçici uluslararası koruma sağlamaktadır. Dolayısıyla Suriye'den Türkiye'ye gelen göçmenleri Türk ulusal mevzuatı itibarıyla mülteci konumunda değerlendirmek mümkün olmamaktadır. Bkz. Barış Özdal-Esra Vardar Tutan, "Suriye'den Türkiye'ye Yönelik Göç Hareketlerinin Türkiye-Avrupa Birliği İlişkilerine Etkilerinin Analizi”, II. Uluslararası Göç ve Mülteci Kongresi Bildirileri: Göç Yönetimi ve Göçmenlerin Entegrasyonunda Başarılı Yönetsel Modeller, 6-7-8 Aralık 2018 - Düzce, 107-127, ss. 110-111. Söz konusu durum doğal olarak İran, Irak, Afganistan, Sudan gibi ülkelerden Türkiye'ye gelerek iltica talebinde bulunan kişiler için de geçerliliğini korumaktadır. Ancak uluslararası alanda Suriyeli göçmenler konusu işlenirken, bu kitleyi tanımlamak için "mülteci" kavramının sıklıkla kullanıldığını belirtmek gerekir. Bu çalışmada da Suriyeli "göçmenler" ve "mülteciler" kavramları eș anlamlı olarak kullanılmıștır.

${ }^{24}$ The UN Refugee Agency, "Syria Regional Refugee Response", https://data2.unhcr. 
yanı sıra Batı Anadolu'daki İstanbul, İzmir, Bursa ve Kocaeli gibi büyükşehirlerinde de geçici uluslararası koruma altında yüzbinlerce Suriyeli göçmen bulunmaktadır.

Tablo I. Suriyeli Göçmenlerin Ülkelere Göre Dağılımı ${ }^{25}$

\begin{tabular}{|c|c|}
\hline Türkiye & 3.583 .584 \\
\hline Lübnan & 910.256 \\
\hline Ürdün & 656.213 \\
\hline Irak & 247.440 \\
\hline Misır & 130.074 \\
\hline Diğer Yerler (Kuzey Afrika) & 31.657 \\
\hline
\end{tabular}

Tablo I.'de görüldüğü üzere, Suriye İç Savaşı'nın somut çıktılarından biri olarak göç, öncelikle Suriye'nin komşu ülkelerine yönelik gerçekleşmiştir. Bu bağlamda, Türkiye en fazla sayıda Suriyeli göçmene ev sahipliği yapan ülkedir. Her ne kadar Ankara yönetimi bu göç dalgasını oluşturduğu kurumlar, gerçekleştirdiği hukuki düzenlemeler ve ayırdığı ekonomik kaynaklarla kendi imkânları kapsamında yönetmeye çalışsa da Suriyeli göçmenlerin AB ülkelerine yönelik göç girişimleri bu konuyu Türkiye-AB ilişkilerinin önemli bir parçası haline getirmiştir. Diğer bir deyişle Suriyeli göçmenler meselesi $A B$ üzerinde baskı oluşturmuş ve Türkiye'nin $A B$ ile ilişkilerinde önemli bir konu başlığ haline gelmiştir. ${ }^{26}$

$\mathrm{Bu}$ çerçevede, Türkiye'ye komşu bir ülke olan Bulgaristan, Suriyelilerin Türkiye üzerinden Batı Avrupa'ya yönelik göç etme girişimlerini ulusal güvenliğine tehdit olarak algılamıştır. Her ne kadar

\footnotetext{
org/en/situations/syria, (Erişim tarihi: 18.04.2020).

${ }^{25}$ Ibid.

${ }^{26}$ Barış Özdal ve Esra Vardar Tutan, “Avrupa Birliği’nin Düzenli Göç Politikası'nın Türkiye'ye Etkileri”, Uluslararası Göç ve Nüfus Hareketleri Bağlamında Türkiye, (ed. Barış Özdal), Dora Yayınları, Bursa, 2018, 271-296, s. 286.
}

\section{5}

Güvenlik Stratejileri

Cilt: 16

Say1: 35 

Bulgaristan'ın coğrafi konumundan kaynaklı olan bu güvenlik algıs1, Suriyeli göçmenler için bir varış noktası olmamasına karşın Sofya yönetiminin Brüksel'e baskı yapmasını beraberinde getirmiştir. Bu bağlamda Bulgar karar alıcılar AB'ye Suriyeli mülteciler konusuna çözüm noktasında baskıda bulunmuştur.

Suriyeli göçmenlere yönelik Bulgaristan'ın politikasına değinmeden önce Bulgaristan Cumhuriyeti'nin Ulusal Güvenlik Stratejisi Belgeleri'nde göç konusunun nasıl algılandığını genel hatlarıyla ele almak gerekmektedir. 1989' da ülkede komünist rejiminin yıkılmasının ardından ulusal güvenlik stratejisini tespit ve somutlaştırma noktasında sorunlar yaşayan Bulgaristan, bu konudaki ilk somut adımını 22 Nisan 1998'de Ulusal Güvenlik Konsepti (Kontseptsiya za Natsionalnata Sigurnost na Republika Bilgariya)'ni yürürlüğe koyarak atmıştır. ${ }^{27}$ Söz konusu Konsept, Bulgaristan'ın demokratik dönemde siyasal elitlerinin girişimleriyle güvenliğine yönelik belli bir vizyon ve prensipler etrafında oluşturduğu ilk belge olması açısından önem taşımaktadır. ${ }^{28}$ Bulgaristan'ın Avro-Atlantik kurumlara üyelik hedefini dış politikasının merkezine konumlandırdığı anlaşılan Konsept'te ülkenin toprak bütünlüğünün, sınırlarının ve devletin bağımsızlı̆̆ının korunmasının yanı sıra anayasal düzenin muhafazası ve Bulgaristan vatandaşlarının bireysel hak ve özgürlüklerinin sağlanması gibi temel hedeflerin yeni güvenlik tehditlerini de içerecek şekilde yer aldığ 1 görülmektedir. Konumuz açısından bakıldığında, Ulusal Güvenlik Konsepti'nin 18. maddesinde Bulgaristan'1n komünizmden demokrasiye geçişinden sonra uyumun sağlanamaması ve kurumlar arası çatışmaların da etkisiyle ortaya çıkan ekonomik krizlerin sonucu olarak ülkeden eşi ve benzeri görülmemiş bir göç yaşandığı belirtilmektedir. ${ }^{29} \mathrm{Bu}$ Konsept'te göç konusuna sadece bir kere değinildiği dikkat çekmekte olup ülkeye yönelik göçlerden ziyade ülkeden yaşanan göçler ele alınmaktadır.

${ }^{27}$ Bkz. Dirjaven Vestnik, Broi: 46, 22 April 1998.

${ }^{28}$ Blagovest Tashev, "In Search of Security: Bulgaria's Security Policy in Transition", Papeles del Este, No: 8, 2004, 1-20, p. 3.

${ }^{29}$ Dirjaven Vestnik, Broi: 46, 22 April 1998. 
Göçün Güvenlikleştirilmesi Bağlamında

Bulgaristan'ın Suriyeli Göçmenlere Yönelik Politikası

Ulusal Güvenlik Konsepti yerini 8 Mart 2011'de Bulgaristan devletinin resmî gazetesi olan Dirjaven Vestnik'te yayınlanarak yürürlüğge giren Bulgaristan Cumhuriyeti Ulusal Güvenlik Stratejisi (Strategiya za Natsionalna Sigurnost na Republika Bllgariya)'ne bırakmıştır. ${ }^{30}$ Bulgaristan Hükümeti tarafından hazırlanan 2011 Ulusal Güvenlik Stratejisi, Bulgaristan Parlamentosu (Slbranie) tarafindan kabul edilen kararla işlevsel hale gelmiştir. Bu Strateji Belgesi'nde Bulgaristan açısından hayatî öneme sahip olan çıkarlar birey, toplum ve devlet bazında üç seviyeli olarak ele alınırken hak ve özgürlüklerin korunması, refah ve güvenliğin sağlanması esas olmuştur. Ayrıca ülkenin toprak bütünlügünün korunmas1, ulusun birliğinin savunulmas1, demokratik değerlerin ve anayasal sistemin muhafazası gibi önceliklere de yer verilmiştir. Söz konusu Ulusal Güvenlik Stratejisi Belgesi'nde yeni ortaya çıkan risk ve tehditler kapsamında ise uluslararası terörizmi ve kitle imha silahlarını içeren asimetrik tehditler, bölgesel çatışmalar, siber suçlar, organize suç örgütleri gibi hususlar da yer bulmuştur. ${ }^{31}$ Suriye'de iç savaşın başlangıcı olarak kabul edilen 15 Mart 2011 tarihinden sadece bir hafta önce yürürlüğe giren Ulusal Güvenlik Stratejisi'nde uluslararası göç konusuna da vurgu yapılmıştır. Belgede altı defa göç kelimesi yer alırken, 83. maddede Bulgaristan'dan yaşanan göçlerin haricinde 24., 34., 42., 54. ve 136. maddelerde uluslararası göçlerin artış kaydettiğine ve Üçüncü Dünya ülkelerindeki gelişmelerin AB'nin dış sınırı olarak Bulgaristan üzerinde baskı yarattığına değinilmiştir. Orta Doğu kaynaklı tehditlerin ele alındığı 42. maddede ise bölgedeki gelişmelerin uluslararası terörist ağların hareketliliği, radikal akımların nüfuzu ve daha güçlü bir göç baskısının belirgin bir risk oluşturduğu kaydedilmiştir. Bu madde, takip eden yıllarda Suriye İç Savaşı'nın neden olduğu göç dalgasında görüleceği üzere Bulgaristan'ın söz konusu tehdit algılamasını doğrulamıştır.

2020 yılına kadar yürürlükte kalması öngörülen 2011 Ulusal Güvenlik Stratejisi ortaya çıkan yeni güvenlik tehditleri nedeniyle Mayıs

\footnotetext{
${ }^{30}$ Dirjaven Vestnik, Broi: 19, 8 Mart 2011.

${ }^{31}$ Ibid.
}

\section{7}

Güvenlik Stratejileri

Cilt: 16

Say1: 35 
2017'de göreve başlayan Borisov-III Hükümeti'nin girişimleriyle revize edilmiştir. Aralık 2017'de Bulgaristan Parlamentosu'na getirilen ve 23 Mart 2018 tarihinde Bulgaristan devletinin resmî gazetesi olan Dirjaven Vestnik'te yayınlanan ${ }^{32}$ yeni Ulusal Güvenlik Stratejisi, hâlihazırda yürürlükte olması nedeniyle büyük önem taşımaktadır. Ayrıca söz konusu Ulusal Güvenlik Stratejisi'nin hazırlanmasında aşağıda inceleneceği üzere, Bulgaristan'ın Eylül 2015'te karşılaştığı ve etkileri 2017 yılı itibarıyla devam etmekte olan göç akınının önemli bir rol oynadığı belirtilmelidir. ${ }^{33} \mathrm{Bu}$ çerçevede Ulusal Güvenlik Stratejisi'nde "göç" kavramının anahtar kelime olarak 15 defa kullanıldığı görülmektedir.

Daha geniş bir biçimde belirtirsek, 2018 yılı Ulusal Güvenlik Stratejisi'nin Üçüncü Bölümü'nde "Güvenlik Çevresi: Risk ve Tehditler" başlığı altında dış ve iç güvenlik tehditlerine yer verilmiştir. Dış güvenlik tehditleri kapsamında Bulgaristan'ın güvenliği açısından yeni risk ve tehditlerin ortaya çıktığı belirtilirken, devam eden göç baskısına (24. madde) atıfta bulunulmuştur. Belgede, göç konusuna en kapsamlı vurgu ise 30. maddede yapılmıştır. İlgili maddede göçün uzun vadeli ve gittikçe derinleşen bir problem haline geldiği, yönetilmemesi halinde hem transit (geçiş) hem hedef ülkelerde demokratik toplumlar ve ekonomiler için stratejik tehdit oluşturacağı ifade edilmektedir. Orta Doğu, Orta Asya ve Afrika'daki genel durumun Avrupa ülkelerinin ve Bulgaristan'ın güvenliği açısından olumsuzluk yaratan göç baskısını oluşturduğunun belirtilmesinin yanında Bulgaristan'ın coğrafi konumu nedeniyle sınırlarında devamlı yasadışı göç akımına maruz kalma ihtimali olduğuna değinilmektedir. Söz konusu süreçlerin ortaya çıkmasının siyasi, ekonomik, toplumsal ve sağlık alanlarında ülkenin

\footnotetext{
${ }^{32}$ Dirjaven Vestnik, Broi: 26, 23 Mart 2018.

${ }^{33}$ Söz konusu Ulusal Güvenlik Strateji Belgeleri'nin yeni ortaya çıkan tehditler söz konusu olduğunda revize edilebildiğini not etmek gerekir. Örneğin Nisan 2016' da Borisov savunma sanayindeki şirketlerin özelleştirilmesini engellemiştir. Bkz. Defence24, "Bulgaria Updates Its Security Strategy And Suspends Privatization of the Defence Industry", 17 Kwietnia 2016, https://www.defence24.com/bulgaria-updates-its-security-strategy-and-suspendsprivatization-of-the-defence-industry, (Erişim tarihi: 20.03.2020).
} 
ulusal güvenliğine yönelik bir dizi riskin ana çerçevesini teşkil ettiği de kaydedilmiştir. Ayrıca ilgili madde kapsamında, göçmenlerin arasına sızan yabancı savaşçıların ülkeden geçme riskinin özellikle marjinal sosyo-ekonomik durumda bulunan kişi ve grupların radikalleşmesine neden olmakla birlikte, Bulgaristan'da terörist ve lojistik hücrelerin oluşması için altyapı yaratacağı da vurgulanmaktadır.

2018 Ulusal Güvenlik Stratejisi'nin 46. maddesinde Bulgaristan'1n belirtilen pek çok alanda olduğu gibi göç akınının yönetilmesi ve dış sınırlarının korunması hususunda da $\mathrm{AB}$ ile iş birliğgi yapacağı belirtilmiştir. Öte yandan Dublin Sözleşmesi'nin gözden geçirilmesini içeren ve iç güvenlikle ilgili kısımda yer verilen 61. maddede ise Bulgaristan'ın sosyo-ekonomik yaşamına entegre olmakla ilgilenmeyen göçmenlerin büyük çoğunluğu tarafindan ülkenin bir geçiş noktası olarak görüldüğü ifade edilirken, bunun yasadışı insan ticareti gibi kriminal faaliyetlerin artışına zemin hazırladığına yer verilmektedir. Bilindiği üzere, 2013'te yürürlüğe giren Dublin Sözleşmesi bir AB düzenlemesi olup 1951 Cenevre Sözleşmesi ve AB Vasıf Yönergesi (EU Qualification Directive) kapsamında uluslararası koruma isteyen kişilerce yapılan sığınma başvurusunu üye devletin sorumluluğuna vermektedir. $^{34}$ AB'nin dış sınırlarından biri durumunda bulunan Bulgaristan, Yunanistan ile birlikte Orta Doğu ve Afrika kaynaklı göçlerin ilk varış noktalarından birisidir ve bu coğrafi durum Bulgaristan üzerindeki göç baskısını artırmaktadır.

Genel güvenlik değerlendirmesinin yapıldığı 69. maddede ise Bulgaristan'ın ulusal güvenliğine tehdit oluşturan unsurlar, devletlerin konvansiyonel olmayan baskı metotları, provokatif askerî faaliyetleri, bölgesel krizler ve çatışmalar şeklinde sıralanırken, terörist faaliyetler ile bunların neden olduğu göç ve mülteci akımına da yer verilmiştir. Aynı maddede risk potansiyelinin devlet dışı aktörlerin de dâhil olduğu

\footnotetext{
${ }^{34}$ Dublin Sözleşmesi için bkz. Official Journal of the European Union, "Regulation (EU) No 604/2013 of the European Parliament and of the Council of 26 June 2013", L 180/31, 29.06.2013, https://eur-lex.europa.eu/LexUriServ/LexUriServ.do?uri=OJ:L: 2013:180:0031:0059:EN:PDF, (Erişim tarihi: 22.03.2020).
}

\section{9}

Güvenlik Stratejileri

Cilt: 16

Say1: 35 
Güvenlik Stratejileri

Cilt: 16

Sayı: 35

asimetrik ve hibrid tehditlerin yanı sıra askerî çatışma olasıllı̆̆ını da içerdiği görülmektedir. Dolayısıyla göç ve mülteci hareketleri Bulgaristan açısından ulusal güvenlik tehdidi olarak tanımlanmıştır.

Analiz ettiğimiz, Ulusal Güvenlik Stratejisi Belgeleri'nin Bulgaristan'ın resmî söylemi olduğu dikkate alındığında, Bulgar siyasal elitlerinin görüşlerini içerdiği ve bunun kamuoyunca kabul edildiği ileri sürülebilir. $\mathrm{Bu}$ açıdan göç hususunda başarılı bir güvenlikleştirmeden bahsetmek mümkündür. Bulgaristan'a yönelik Suriyeli göçmen baskısının arttığı dönemlerde Başbakan Boyko Borisov'un söylemleri de bu değerlendirmemizi desteklemektedir.

\section{Bulgaristan'ın Göçü Güvenlikleştirmesi}

Bulgaristan'in Ulusal Güvenlik Stratejisi Belgeleri çerçevesinde uluslararası göç konusuna önem vermesinin Suriye menşeli olası kitlesel göçlerden kaynaklandığı görülmektedir. Bu noktada 3,5 milyon civarında Suriyeli göçmene ev sahipliği yapan Türkiye üzerinden yaşanabilecek kitlesel göçler Sofya yönetimini güç durumda bırakma potansiyeli taşımaktadır. Esasen bu süreçte Bulgaristan açısından Suriyeli göçmen krizi önemli kırılma anlarıyla ilintili olarak üç ayrı dönemde ele alınabilir:

1. 15 Mart 2011 - 15 Eylül 2015 tarihleri arası süreci kapsayan düşük yoğunluklu göç dönemi,

2. 15 Eylül 2015 - 18 Mart 2016 tarihleri arasını içeren kriz dönemi,

3. 18 Mart 2016 - 28 Şubat 2020 tarihleri arasındaki istikrar dönemi.

Düşük yoğunluklu göçleri içeren ilk döneme bakıldığında, 2011 ve 2012 yıllarının Bulgaristan açısından tehdit oluşturmadığı görülürken, özellikle 2013 yılının ikinci yarısından itibaren Suriyelilerin göç hareketleri ülke kamuoyunda tartışılır hale gelmiştir. Esasen 2013 yılının başından itibaren Suriyeli göçmenlerin düşük sayılarda ülkeye giriş yapmaya başladıkları dikkat çekse de konu o dönemde Bulgaristan'ın hareketli siyasi gündeminde yer bulamamıştır. Zira Şubat 2013 itibarıyla ekonomik sorunları ve düşük yaşam standartlarını ileri sürerek başkent Sofya başta olmak üzere ülke genelinde protesto gösterileri yapılmış ve 
Göçün Güvenlikleştirilmesi Bağlamında

Bulgaristan'ın Suriyeli Göçmenlere Yönelik Politikası

nihayetinde Başbakan Borisov istifa etmek zorunda kalmıştır. ${ }^{35}$ 12 Mayıs 2013'te yapılan erken Genel Seçimler'in ardından Plamen Oreşarski'nin Başbakanlığında koalisyon hükümetinin kurulmasının ardından Suriyeli göçmenler konusu daha güçlü bir şekilde tartışılmaya başlanmıştır.

Bulgaristan Başbakanı Oreşarski Kasım 2013'te Parlamento'da yaptığı açıklamada yasadışı göçmenlerin iade edileceğini ifade ederek göçmen krizi için yılsonuna kadar 20 milyon Leva harcayacaklarını ve Bulgaristan sınırlarının AB'nin sınırları olması nedeniyle ülkenin $\mathrm{AB}$ 'nin yardımını istemesi gerektiğini söylemiştir. ${ }^{36} \mathrm{Bu}$ dönemde Bulgaristan'da yasadışı göçmen sayısı 10 bine yaklaşırken, Avrupa Parlamentosu (AP)'nda milletvekilliği yapan İliyana İotova ise Arap Baharı'nın başlamasından itibaren Bulgaristan'a gelen mülteci sayısının \%206 oranında arttığını belirterek bütün Avrupa'nın şaşkın ve hazırlıksız olduğunu açıklamıştır. ${ }^{37}$ Bulgar Savunma Bakanı Angel Naydenov’un mülteci akınının Bulgaristan'ın ulusal güvenliğine tehdit olduğunu ifade etmesi ise Sofya yönetiminin meseleye bakış açısını özetlemektedir. ${ }^{38}$ Görüldüğü üzere göçmen krizi Bulgar karar alıcılar tarafından güvenlikleştirilmeye başlanmış ve Bulgar kamuoyu ikna edilmiştir.

2014 yılı itibarıyla gerek AB'nin sembolik fon aktarımı gerek ülkedeki iç siyasi tartışmaların gölgesinde kalan Suriyeli göçmenler krizi, 5 Ekim 2014'te yapılan erken Genel Seçimler'den sonra Başbakan olan Borisov ile birlikte yeniden yükselişe geçmiştir. Ancak 2013'ün ikinci yarısına tezat olarak tartışmaların cılız bir düzeyde

\footnotetext{
${ }^{35}$ Kader Özlem, Türkiye-Bulgaristan İlişkileri ve Türk Azınlık, Dora Yayınları, Bursa, 2019, ss. 195-196.

${ }^{36}$ Narodno Sibranie na Republika Bılgariya, "Zaştitnata Stena po Granitsata s Turtsiya Şte Bide Gotova v Sikrateni Srokove Zayavi Ministır-Predsedatelyat Plamen Oreşarski po Vreme na Parlamentarniya Blitskontrol", 06.11.2013, https://parliament.bg/bg/ news/ID/2799, (Erişim tarihi: 24.03.2020).

${ }^{37}$ Duma, "Tryabva da Dadem Otpor na Ksenofobiyata", 23 Noemvri 2013.

38 BTV, "Bejanskata Vilna - Zaplaha za Natsionalnata Sigurnost", 7.10.2013, https://btvnovinite.bg/bulgaria/politika/bezhanskata-valna-zaplaha-za-natsionalnatasigurnost-na-balgariya.html, (Erişim tarihi: 25.03.2020).
}

\section{1}

Güvenlik Stratejileri

Cilt: 16

Say1: 35 
572

Güvenlik Stratejileri

Cilt: 16

Sayı: 35 kaldığı görülmektedir. Bunun temel nedeni ülkeye gelerek uluslararası koruma talebinde bulunan mülteci sayısında artışa rağmen, sorunun Bulgaristan açısından hâlen yönetilebilir olmasından kaynaklanmaktadır.

Tablo II. Bulgaristan Bakanlar Kurulu'na Bağlı Mülteciler için Devlet Ajansı Verileri İtibarıyla 01.01.2010-31.12.2019 Döneminde Koruma Talebinde Bulunan Birey Sayısının Yıllara Göre Dağılımı ${ }^{39}$

\begin{tabular}{|c|c|}
\hline YIL & Kiși SAYI \\
\hline 2010 & 1.025 \\
\hline 2011 & 890 \\
\hline 2012 & 1.387 \\
\hline 2013 & 7.144 \\
\hline 2014 & 11.081 \\
\hline 2015 & 20.391 \\
\hline 2016 & 19.418 \\
\hline 2017 & 3.700 \\
\hline 2018 & 2.536 \\
\hline 2019 & 2.152 \\
\hline
\end{tabular}

Kriz dönemi olarak adlandırdığımız ikinci aşamada ise 15 Eylül 2015 tarihinde binlerce Suriyeli göçmenin Edirne'ye doğru hareket etmesi Bulgar karar alıcıları harekete geçirirken, kamuoyunda da infial etkisi yaratmıştır. Zira binlerce göçmenin Bulgaristan'a akın etmesinin ekonomik ve toplumsal açıdan yüksek maliyetler getireceğini düşünen Sofya yönetimi, bunu önlemek için aktif bir diplomasi yürütmüştür. Başbakan Borisov bir taraftan Türkiye Cumhurbaşkanı Recep Tayyip

${ }^{39}$ Bulgaristan'ın Mülteciler için Devlet Ajansı'nın verileri için bkz. Dırjavna Agentsiya za Bejantsite pri MS, "Grafiki", http://www.aref.government.bg/sites/default/files/ uploads/docs/2020-03/7\%20-\%20Charts-website-bg_12.pdf, (Erişim tarihi: 25.03.2020). 
Erdoğan ile diyalog içinde bulunurken diğer taraftan AB'yi eleştirmiştir. Esasen bu dönemde Bulgaristan'a benzer şekilde Yunanistan'1 da tehdit eden söz konusu durum, Atina yönetiminin ekonomik kriz içinde olması ve bunun için AB'den sağladığı krediler nedeniyle Brüksel'e karşı eleştirel bir söylem geliştirmesini engellemiştir.

Başbakan Borisov'un bu dönemde Türkiye'yle iyi diyalog halinde olma çabası Suriyeli göçmenlere ilişkin Ankara'nın elinin güçlü olmasından kaynaklanmaktadır. Zira Türkiye'nin Bulgaristan'a yönlendireceği yüzbinlerce göçmenin ülkede yaratacağı sorunların farkında olan Borisov, göçmen hareketliliğinin başladığı andan itibaren konuyu dikkatle takip etmiştir. Nitekim Türk tarafı Edirne'ye ulaşan göçmenleri geri döndürme kararı alırken Bulgaristan için tehlike ötelenmiş ve bunun üzerine Borisov, böylesi bir akının kendileri açısından nelere yol açacağını gördüğü ve dayanışma gösterdiği için Erdoğan'a teşekkürlerini sunmuştur. ${ }^{40}$ Mülteci akınına karşı askerî kuvvete ihtiyaç duyulmadığını söyleyen Borisov, 1.200 kadar mülteciyi kabul edebileceklerini de ifade etmiştir. ${ }^{41}$ Bu durum Bulgaristan'ın diplomasi aracılığıyla sonuç elde ettiğini somut bir biçimde göstermektedir.

15 Eylül 2015 tarihli bu gelişme AB sistemi içerisinde de derin tartışmalara yol açmıştır. Mültecileri kabul etme konusunda istekli olmayan Brüksel, Bulgaristan'ın yanı sıra Yunanistan'ın da eleştirileri üzerine Türkiye ile göçmenler konusunda yeni ortaya çıkan gelişmeleri (AB sınırlarına yönelik kitlesel göç hareketliliği, Ege Denizi'nden yasadışı göçmen geçişleri, Balkanlar'da mültecilerin varlığının artmaya başlaması vb.) dikkate alarak uzlaşıya varmaya çalışmıştır. Esasen 01.10.2014 tarihinde yürürlüğe giren ve "Geri Kabul Anlaşması" olarak da bilinen "Türkiye ile AB Arasında İzinsiz İkamet Eden Kişilerin Geri Kabulüne İlişkin Anlaşma" ${ }^{42}$ ile Türkiye ve $\mathrm{AB}$ üyesi devletlerin ülkeleri arasında

\footnotetext{
${ }^{40}$ Dnes, “Borisov Prati Pozdravi na Erdogan: Blagodariya Ti!”, 19 Septemvri 2015.

${ }^{41}$ Trud, "Premierıt Boiko Borisov: Nyama Nujda ot Armiya na Granitsata s Turtsiya", 18.09.2015.

${ }^{42}$ 16.12.2013'te Türkiye ile AB arasında imzalanan ve 25.6.2014 tarih ve 6547 Sayılı Kanun ile onaylanması uygun bulunan antlaşmanın tam metni için bkz. T.C. Resmî
}

573

Güvenlik Stratejileri

Cilt: 16

Say1: 35 
yaşanan yasadış1 göçe ilişkin temel bir çerçeve oluşturulmuştur. $\mathrm{Bu}$

Güvenlik Stratejileri

Cilt: 16

Sayı: 35 Anlaşma, yasadışı yollarla $\mathrm{AB}$ üyesi devletlerin ülkelerine giden veya bu ülkelerde bulundukları sırada yasadışı duruma düşen Türkiye Cumhuriyeti Devleti vatandaşları ve Türkiye üzerinden Anlaşmaya taraf olan diğer devletlerin ülkelerine geçiş yapmış üçüncü devlet vatandaşlarının Anlaşmada belirlenen normlar kapsamında Türkiye'ye geri gönderilmesini öngörmektedir. ${ }^{43}$ Anlaşma karşıl1l1k içermekte olup Türkiye'de bulundukları sürede yasadışı duruma düşen kişilerin de ilgili $A B$ üyesi devlete iade edilmesini kapsamaktadır. Ne var ki yukarıda bahsedilen yeni gelişmeler Türkiye ile $\mathrm{AB}$ arasında yasadışı göçmenler konusuna ilişkin diyaloğun geliştirilmesini tetiklemiştir.

$\mathrm{Bu}$ süreçte $\mathrm{AB}$ 'nin Bulgaristan'ın güvenlik endişelerini dikkate almadığını sıç̧a vurgulayan Borisov, 24 Eylül 2015'te Sofya'da düzenlenen "Mülteci Akını ve Millî Güvenliğin Önündeki Zorluklar (Bejanskata Vilna i Predizvikatelstvata pred Natsionalnata Sigurnost)" başl1klı Ulusal Konferansa katılarak "Bulgaristan 100.000 veya 200.000 mülteciyi almak zorunda mıdır?" sorusunu sormuştur. ${ }^{44}$ Edirne'nin Bulgaristan sınırına çok yakın olduğunu da söyleyen Bulgar Başbakanı, Türkiye'yle olan sınırlarının Türkiye-Yunanistan sınırından daha az olmadığını belirtmiştir. ${ }^{45}$ Borisov aynı konferansta $\mathrm{AB}$ liderleriyle göçmen krizini görüştüğünü ifade etmiş, Bulgaristan'a Yunanistan ve İtalya ile aynı muameleyle davranılmadığını, diğer ülkeler AB'nin dış sınırı olarak algılanırken Bulgaristan'ın ise bu şekilde değerlendirilmediğini dile getirmiştir. Zira bu devletlerin göçmenlerle ilgili harcamaları

Gazete, 02.08.2014, Sayı: 29076. Anlaşmada vize muafiyeti konusunun da ele alındığını da belirtmek gerekir.

${ }^{43}$ Kamuran Reçber, "Türkiye Cumhuriyeti Devleti ile Avrupa Birliği Arasında Akdedilen Geri Kabul Anlaşması'nın Yaratabileceği Sonuçların Analizi”, Uluslararası Göç ve Nüfus Hareketleri Bağlamında Türkiye, (ed. Barış Özdal), Dora Yayınları, Bursa, 2018, 297-314, s. 301.

${ }^{44}$ Boiko Borisov, "V Bryuksel Zaştitih Natsionalnite İnteresi", Bejanskata Vllna i Predizvikatelstvata pred Natsionalnata Sigurnost, İnstitut za Strategii i Analizi, Sofiya, 24 Septemvri 2015, 11-15, p. 13.

${ }^{45}$ Borisov, ibid, pp. 11-13. 
Göçün Güvenlikleştirilmesi Bağlamında

Bulgaristan'ın Suriyeli Göçmenlere Yönelik Politikası

$\mathrm{AB}$ bütçesinden karşılanmasına rağmen Bulgaristan'ın kendi hazinesine başvurmak zorunda kalmasını eleştirmiştir. ${ }^{46} \mathrm{Bu}$ süreçte Bulgaristan, AB'nin Schengen bölgesine dâhil olmak için göçmen krizini kullanmaya çalışmışsa da bunda başarılı olamamıştır.

15 Eylül 2015 tarihi sonrasındaki gelişmelerin sonucu olarak Balkanlar'ın mültecilerin Batı Avrupa'ya ulaşmak için bir geçiş koridorunu andıran imaja bürünmesi Bulgaristan'1 endişelendirmiştir. Zira bu dönemde Almanya'nın ve Avusturya'nın sınırlarını kapatma ihtimali Bulgaristan'1 ürkütürken Ekim 2015'te verdiği demeçte Başbakan Borisov Bulgaristan'1, Romanya'y1 ve Sirbistan'1 kastederek ülkelerinin tampon bölge olmasına izin vermeyeceklerini belirtmiştir. ${ }^{47}$ $\mathrm{Bu}$ dönemde $\mathrm{AB}$ üyesi devletlerin Birlik çıkarından ziyade kendi çıkarlarına odaklandığı görülmüştür.

2015 ve 2016 y1lı gelişmeleri AB'nin Türkiye ile mülteci krizi konusunda müzakerelere girişmesine neden olmuş ve 18 Mart 2016 tarihli Türkiye-AB Zirvesi Bildirisi ${ }^{48}$ ilan edilmiștir. Türk kamuoyunda "18 Mart Mutabakatı" olarak da bilinen bu Bildiri" ${ }^{49}$, Kasim 2015'ten itibaren Türkiye ile $\mathrm{AB}$ arasında yapılan üçüncü toplantının ardından ilan edilmiş olup tarafların Türkiye'den AB'ye gerçekleşen düzensiz

\footnotetext{
${ }^{46}$ Borisov, ibid, p. 15.

${ }^{47}$ BNR, "Boiko Borisov: Nyama da Ostavim Narodite Ni da Stanat Buferna Zona", 24.10.2015, https://bnr.bg/sofia/post/100617075/boiko-borisov-nama-da-ostavim-naroditeni-da-stanat-buferna-zona, (Erișim tarihi: 25.03.2020).

${ }^{48}$ Tam metni için bkz. T.C. Dışişleri Bakanlığı - AB Başkanlı̆̆ Resmî Internet Sayfası, "18 Mart 2016 tarihli Türkiye-AB Zirvesi Bildirisi”, https://www.ab.gov.tr/files/AB Iliskileri/18 mart 2016 turkiye ab zirvesi_bildirisi_pdf, (Erişim tarihi: 22.03.2020); European $\bar{C}$ ouncil - Council of the European Union, "EU-Turkey Statement, 18 March 2016", https://www.consilium.europa.eu/en/press/press-releases/2016/03/18/eu-turkeystatement/, (Erişim tarihi: 22.03.2020).

${ }^{49} 18$ Mart tarihli Mutabakat, Türkiye ile $\mathrm{AB}$ arasında düzensiz göçe son verme amacında olmakla birlikte, uygulama alanı Ege Denizi'nde kaçak olarak yakalanan göçmenlerin geri alınması üzerine inşa edilmiştir. 18 Mart Mutabakatı ile Geri Kabul Anlaşması birbiriyle karıștırılmakta olup bu Mutabakat doğrudan değil, dolaylı olarak Geri Kabul Anlaşması'yla alakalıdır. Bkz. Reçber, agm, s. 307. Mutabakatta, vize serbestiyle ilgili düzenlemelerin yer aldığını da belirtmek gerekir.
}

575

Güvenlik Stratejileri

Cilt: 16

Say1: 35 
göçü sonlandırma kararlılığını yansıtmaktadır. 18 Mart Mutabakatı düzensiz göçü sona erdirme amacı taşıması nedeniyle Bulgaristan'ın

Güvenlik Stratejileri

Cilt: 16

Sayı: 35 endişelerinin giderilmesinde önemli olmuştur. Zira 5 Mayıs 2016 tarihinde Türkiye ile AB arasında imzalanan Geri Kabul Anlaşması'nın Türkiye ile Bulgaristan arasında uygulamasını esas alan bir Protokol de imzalanmıştır. ${ }^{50}$ Söz konusu diplomatik belgelerle Bulgaristan açısından 28 Şubat 2020 tarihine değin kitlesel göçmen baskısının makro öncelikli bir konu olması ötelenmiştir.

$\mathrm{Bu}$ bağlamda, 18 Mart 2016 tarihi sonrasındaki süreci kapsayan üçüncü dönemde mülteci tehdidi devam etse de kendi içinde istikrarlı bir tablo dikkat çekmektedir. Ancak Bulgar karar alıcılar göçün güvenlikleştirilmesini sürdürmüş ve Bulgaristan'ın politikasında söylem-eylem uyumu gözlenmiştir. Örneğin 18 Mart Mutabakatı'nın ardından Bulgaristan, 2013'te kararı alınan ve Türkiye ile olan sınır bölgesinde tel örgülü duvar inşasına yönelik faaliyetlerini hızla devam ettirmiştir. $^{51}$ Her ne kadar tel örgülü duvar önlemi kaçak geçişleri önlemede yetersiz kalsa da yasadışı göçmen sayısının azalmasında yardımcı olmuştur. Ağustos 2016 verilerine bakıldığında, Bulgaristan'ın toplama kampında 2.950, İçişleri Bakanlığı gözetiminde ise 1.445 kişi

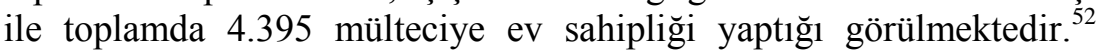
Mülteciler sayisal olarak toplumu rahatsiz etmeyecek bir seviyede bulunmalarına karşın, dönemin gelişmelerine bağlı olarak siyasilerin söylemlerinin güvenlikleştirme kapsamında kamuoyunda karşıllk bulduğu anlaşılmaktadır. Zira 2016 yılı itibarıyla Bulgaristan toplumunun 2/3'ü göçmenlerin ve mültecilerin Bulgaristan'ın ulusal güvenliğine

\footnotetext{
${ }^{50}$ Ministerstvo na Vitreşnite Raboti, Bılgariya i Turtsiya Podpisaha Protokol za Prilagane na Sporazumenieto Mejdu ES i Turtsiya za Readmisiya", 5 Mai 2016, https://www.mvr.bg/ gdgp/начало/преглед/новини/news160505_01, (Erişim tarihi: 23.03.2020). Protokolün resmî adı şu şekildedir: "Türkiye Cumhuriyeti Hükümeti ile Bulgaristan Cumhuriyeti Hükümeti Arasında Türkiye Cumhuriyeti İle Avrupa Birliği Arasındaki İzinsiz İkamet Eden Kişilerin Geri Kabulüne İlişkin Anlaşmanın Uygulama Protokolü”.

51 Dnes, "Nençev: Ogradata s Turtsiya Şte e Zavırşena v Nai-skoro Vreme", 20 Noemvri 2016.

${ }^{52}$ Deutsche Welle, "Borisov: 'Pomognete B1lgariya!"”, 26.08.2016.
} 
yönelik bir tehdit oluşturduğunu düşünmüşlerdir. ${ }^{53}$

Yukarıda bahsettiğimiz çerçevede göç konusu Bulgaristan açısından tehdit olmayı sürdürmüştür. 15 Temmuz 2016'da Türkiye'de yaşanan darbe girişiminin ardından Bulgaristan'a sığınan FETÖ mensubu Abdullah Büyük'ü Türkiye'ye iade etme kararı alan Başbakan Borisov, kamuoyunda kendisine yönelik yükselen tepkilere yanıt olarak "Abdullah Büyük, Türkiye'ye iade ettiğimiz 25.000 kişiden sadece biridir... Yıl başından beri Türk sınırından gelen 25.000'nin üzerinde kişiyi geri gönderdik. Durduruyoruz ve Türkiye'ye iade ediyoruz... Türkiye ile mümkün olan en iyi ilişkileri inşa etmeye çabalamalıyız. Göç dalgasının Bulgaristan'a girmesine izin vermemeliyiz" ${ }^{, 4}$ açıklamasında bulunmuştur. $\mathrm{Bu}$ süreçte $\mathrm{AB}$ ile Türkiye arasında dayanışmanın sürdürülmesini savunan Bulgar karar alıcılar, Suriyeli göçmenlerden kaynaklı endişelerini $\mathrm{AB}$ platformunda sıkça dile getirmiştir. Türkiye'nin Brüksel'den daha yakın olduğunu sıklıkla vurgulayan Başbakan Borisov, mülteci tehdidinin devam ettiğine dikkat çekerek AB'nin Türkiye'ye karşı eleştirilerini durdurmasını istemiştir. ${ }^{55}$

Nitekim Bulgaristan'ın güvenlik endişeleri 28 Şubat 2020 tarihinde yaşanan gelişmelerin ardından haklı çıkmıştır. Suriye'nin İdlib kentinde rejim güçlerinin saldırısında 34 Türk askerinin şehit olmasını müteakip Türkiye'nin ülkesindeki göçmenlerin Avrupa'ya gidişlerine engel olunmayacağı yönelik alınan kararla Türkiye'nin Batı sınırlarında göçmen hareketliliği yaşanmıştır. Esasen Türk kamuoyunda Suriyeli göçmenlerin varlığının ve maliyetlerinin daha baskın bir şekilde tartışıldığ bu dönemde İdlib'te yaşanan gelişmelerin etkisi altında can güvenliği kaygısıyla bir milyona yakın Suriyelinin yeni bir göç akını yaratarak Türkiye'nin güney sınırlarına dayanması Ankara yönetimi

\footnotetext{
53 Ibid.

${ }^{54}$ Borisov'un konuşmasının tamamı için bkz. Nova TV, "Borisov: Otnoşeniyata s Turtsiya sa Vajni Zaradi Migrantite (VIDEO)", 12 Avgust 2016, https://nova.bg/news/view/2016/ 08/12/156182/борисов-отношенията-с-турция-са-важни-заради-мигрантите-видео, (Erişim tarihi: 23.03.2020).

55 Duma, "Borisov Şte İska ot Bryuksel da Spre Napadkite kım Turtsiya”, 12 Oktomvri 2019.
}

\section{7}

Güvenlik Stratejileri

Cilt: 16

Say1: 35 
578

Güvenlik Stratejileri

Cilt: 16

Sayı: 35

açısından ağır bir baskı oluşturmuştur.

$\mathrm{Bu}$ bağlamda Bulgaristan, kendisine yönelebilecek bu mülteci akınını önlemek için harekete geçmiştir. Söylem açısından klasik vurgusunu sürdüren Başbakan Borisov, ülke için mülteci akınının reel bir tehdit olduğunu dile getirmiş ${ }^{56}$ ve konunun ulusal güvenlik meselesi olduğuna dikkat çekmiştir. Eylem bakımından ise Türkiye ile kara sınırına ve deniz bölgelerine kolluk güçlerini sevk eden Bulgaristan, bir taraftan da diplomasi mekanizmasını işletmiştir. Krizin başlangıcından itibaren Türk muhataplarıyla irtibat halinde olan Borisov, 2 Mart'ta Ankara'da Türk Cumhurbaşkanı Erdoğan ile görüşmüştür. Cumhurbaşkanı Erdoğan ile görüşmesi öncesinde Avrupalı liderlerle istişarelerde bulunan Borisov, Fransa Cumhurbaşkanı Emanuel Makron ile yaptı̆̆ 1 telefon görüşmesinde Türkiye'ye mültecilere yeniden bakması için yardım edilmesi gerektiğini söylemiştir. ${ }^{57}$

Erdoğan-Borisov görüşmesinin tek konu başlığı değilse de ana gündemi Suriyeli göçmenler olurken, Borisov Türkiye'nin savlarına destek vermiştir. Göçmen akınının ana hattının Türkiye-Yunanistan kara sinırı olması, buna mukabil Bulgaristan'a kitlesel bir yığılma olmaması ise Sofya yönetimini memnun etmiştir. Zira Türkiye, 18 Mart Mutabakatı'na bağlılığını sürdürdüğünü, buna karşın AB'nin bunu ihlal ettiğini ifade etmiş ve denizden geçişlere müsaade etmemiştir. Bu durum Bulgar tarafının güvenlik kaygılarını azaltmıştır. Görüşmede $A B$ tarafından Türkiye'ye taahhüt edilen kaynağın neden aktarılmadığını anlamadığını söyleyen Borisov, Türk tarafina teşekkür etmiştir. ${ }^{58}$

Görüldüğü üzere Suriyeli göçmenleri ulusal güvenliğine tehdit

${ }^{56}$ BNT 1, "Borisov: İma Realna Zaplaha ot Bejanska Vılna, Usilili sme Maksimalno Granitsata", 28.02.2020, https://news.bnt.bg/news/borisov-ima-realna-zaplaha-ot-bezhanska -valna-usilili-sme-maksimalno-granicata-1040665news.html, (Erişim tarihi: 01.04.2020).

${ }^{57}$ Dnes, "Borisov Zove da Pomogne na Turtsiya za Migranti", 2 Mart 2020.

${ }^{58}$ BNT 1, "Erdogan Otkaza Sreşta s Liderite ot ES Zaradi Dvama Ubiti Migranti na Granitsata Mejdu Gurtsiya i Turtsiya", 02.03.2020, https://news.bnt.bg/news/erdoganotkaza-sreshta-s-liderite-ot-es-zaradi-dvama-ubiti-migranti-na-granicata-mezhdugarciya-i-turciya-1041233news.html, (Erişim tarihi: 01.04.2020). 
Göçün Güvenlikleştirilmesi Bağlamında

Bulgaristan'ın Suriyeli Göçmenlere Yönelik Politikası

olarak algılayan Bulgaristan, göçün güvenlikleştirilmesi hususunda başarılı bir performans sergilemiştir. Bu politikasını aktif bir diplomasi izleyerek ve Türkiye ile iyi ilişkilerini sürdürerek sağlayan Sofya yönetimi, kendisi açısından risk katsayısı en yüksek dönem olan 2015 ve 2020 y1llarındaki göçmen tehdidini sönümlemeyi başarmıştır. 28 Şubat 2020 tarihinden sonra Avrupa'ya yönelik yaşanan mülteci akını Yunanistan'ı oldukça güç durumda bırakmıştır. Türkiye Cumhurbaşkanı Erdoğan'ın 11 Mart 2020 tarihinde yapmış olduğu açıklamada 28 Şubat'tan sonra 150.000 göçmenin Yunanistan'a gittiğine yer verilirken, bunların Yunanistan'da durmadikları Avrupa'ya doğru hareket ettikleri belirtilmiştir. ${ }^{59}$ Diğer taraftan Bulgaristan'ın böylesi bir durumla karşılaşmaması kamuoyunda Borisov'un Erdoğan ile anlaştığı iddialarına neden olsa da ${ }^{60}$ Sofya yönetimi, ulusal güvenliğine yönelik algıladığı bir tehditten korunmayı başarmıştır.

\section{Güvenlik Sektörleri Bağlamında Bulgaristan'a Yönelik Suriyeli Göçmen Tehdidinin Analizi}

Bulgaristan'ın Suriyeli göçmenleri ulusal güvenlik tehdidi olarak algılaması ülkenin içinde bulunduğu şartlarla doğrudan ilintilidir. Zira 2018 Ulusal Güvenlik Stratejisi Belgesi'nde ifade edildiği üzere Bulgaristan'ın siyasi, ekonomik, toplumsal ve sağlık alanlarında makro ölçekli sonuçlar yaratabileceği tahmin edilen göç akımının mevcut düzeni değiştirerek yeni bir sosyo-ekonomik ve siyasi yapı oluşturabilme potansiyeli bulunmaktadır. Bu nedenle güvenlikleştirilen göç tehdidinin ortadan kaldırılması Sofya yönetiminin öncelikli çıkarları arasında yer almaktadır.

Söz konusu güvenlik tehdidini yürürlükteki Ulusal Güvenlik

\footnotetext{
59 Trud, "Erdogan: 150000 Migranti Trignaha kım Girtsiya, Sled Kato Otvorihme Granitsata", 11.03.2020. Türkiye'de bulunan göçmenlerin büyük bir çoğunluğu Suriyelilerden oluşsa da Afganistan, İran, Irak, Pakistan vb. menşeli yüzbinlerce kişinin bulunduğunu da not etmek gerekir. Dolayısıyla 28 Şubat 2020 tarihi sonrasındaki göç hareketliliğinde bu unsurların da yer aldığı görülmüsstür.

${ }^{60}$ Deutsche Welle, “Na Bilgarskata Granitsa e Podozritelno Spokoino. Zaşto?”, 02.03.2020.
}

\section{9}

Güvenlik Stratejileri

Cilt: 16

Say1: 35 
Stratejisi'nde de belirtilen güvenlik sektörleri açısından analiz etmek gerekirse toplumsal güvenliğin ayrılmaz bir bileşeni olan kimlik güvenliğiyle Suriyeli göçmenler arasında paralellik kurulabilmektedir. Zira Suriyeli göçmenlerin Bulgar ulusal kimliğinin öteki tanımında yer aldığ1 ileri sürülebilir. Diğer bir deyişle her ne kadar Orta Asya bağlantılı Türk kökenli bir kavim olsa da kimliğin tarihsel özel süreçlerde değişen niteliğine bağlı olarak Slav dilini ve Ortodoks inanc1 benimseyen modern Bulgaristan'ın kurucuları durumundaki Tuna Bulgarlarının ${ }^{61}$ İslam dinine mensup ve ekseriyeti Arap kökene sahip olan Suriyeli göçmenlere ulusal kimlik tanımında yer vermeleri mümkün gözükmemektedir. Ayrıca modern Bulgar ulusal kimliğinin oluşumunda temel belirleyici olan tarihsel arka plan Suriyelilerin bu çerçevedeki konumu hakkında bilgi sunabilir. Söz konusu husus iki noktada belirgin hale gelmektedir: Birincisi Bulgar tarih yazımı ve ders kitaplarında görülürken, ikincisi ise Bulgaristan'ın 1908'de Osmanlı Devleti'nden bağımsızlığını ilan ettikten sonra 20. yüzyıl boyunca örneklerine rastlanacağı üzere bünyesindeki Müslüman nüfusa yönelik izlediği asimilasyon politikaları olmaktadır. Bulgar tarih yazımı bağlamında örnek vermek gerekirse uzun yıllar Ulusal Tarih Müzesi (Natsionalen İstoriçeski Muzei) Direktörlüğünde bulunan Bojidar Dimitrov'un eserleri ön plana çıkmaktadır. Zira Dimitrov'un çalışmalarında öteki olarak Türk, İslam ve Osmanlı Devleti kavramları somut bir şekilde kendisini göstermektedir. ${ }^{62}$ Benzer nitelikte Bulgaristan tarih ders kitaplarında yer alan öteki vurgusuna özelde Türk ve Osmanlı Devleti/Türkiye genel olarak ise Müslüman karşıtlığ1 şeklinde rastlanmaktadır. ${ }^{63}$

${ }^{61} \mathrm{Bu}$ konuda yapılan çalışma için bkz. Osman Karatay, Yitik Bir Türk Kavmi Bulgarlar, Ötüken Yayınları, Ankara, 2018.

${ }^{62}$ Bkz. Bojidar Dimitrov, Istinskata İstoriya na Osvobojdenieto (1860-1878), Standar İz., Sofiya, 2010; Bojidar Dimitrov, 12 Mita v Bllgarskata Istoriya i Mittt za Batak, Unikart İz., Sofiya, 2015.

${ }^{63}$ Mümün İsov, Nai-Razliçniyat Sised: Obrazıt na Osmantsite (Turtsite) i Osmanskata Imperiya (Turtsiya) v Bılgarskite Uçebnitsi po Istoriya Prez Vtorata Polovina na XX. Vek, Mejdunaroden Tsentır za İzsledvane na Maltsinsvata i Kulturnite Vzaimodeystviya, 
İkinci husus olarak Bulgaristan'ın 1912-1913 Balkan Savaşları ile Krallık ve Komünizm dönemlerinde bünyesindeki Türk ve Müslüman azınlıklara yönelik isim değiştirme, dini vecibelerin yerine getirilmesinin engellenmesi, anadilde konuşmalarının yasaklanması vb. uygulamalarla Bulgarlaştırma endeksli baskı ve asimilasyon politikaları, Sofya yönetiminin kimlik tanımlanmasının eylemsel boyutunu oluşturmaktadır. Kasım 1989'da Jivkov Rejimi'nin yıkılmasının ardından söz konusu politikalar etkinliğini yitirse de Bulgar kamuoyunun kimlik algılamasında radikal bir değişiklik olmamıştır. Örneğin Mart 2020'de Alfa Research tarafından yayınlanan "Çoğunluk ve Azınlıklar: Farklılıklara Yönelik Tutumları (Mnozistvo i Maltsinsva: Naglasi kım Razliçnite)" başlıklı raporda Bulgar halkının Müslümanlara yönelik dini fanatiklik algılaması, çoğunluğun din anlamında en çok Müslümanlardan korkması ile 1984-1989 yılları arasındaki Müslüman Türklere yönelik izlenen asimilasyon politikasını "doğru bir eylem" olarak toplamda \%52'lik bir oranla onaylaması bu kapsamda önemli göstergelerdir. ${ }^{64}$

Yukarıda bahsettiğimiz hususların dışında, Suriyeli göçmenlerin Bulgar karar alıcilar tarafindan ulusal güvenlik tehdidi olarak algilanmasının en önemli sebebi demografik kaygılardan kaynaklanmaktadır. Başbakan Borisov, 24 Eylül 2015'te yaptı̆̆ konuşmada söz konusu tehdidi net olarak saptamaktadır: “...Bulgaristan'da demografi faktörünün olduğunu ayrıntılı olarak (Avrupa) Konseye aktardım. Karışık bölgelerde Müslümanlara sahibiz, sağ ve hoş olsunlar, ama eğer oraya 100.000-200.000 daha Müslüman ilave edersek dini değişim olacak...". ${ }^{65}$ Borisov'un dile getirdiği bu husus ülkenin genel nüfus yapısı dikkate alındığında daha anlamlı hale gelmektedir.

\footnotetext{
Sofiya, 2005.

${ }^{64}$ Alpha Research, "Mnozistvo i Maltsinsva: Naglasi kım Razliçnite", p. 18, p. 24 and pp. 41-43. https://alpharesearch.bg/api/uploads/Articles\%202020/March\%20-\%20Religions/ final_analyse_results_graphics_31_03_2020.pdf?fbclid=IwAR3ViQ_T6L6MtoPvL6tySvw QANIpqu3cLLpn1bUUZGV3oWEb2JIPgY3AsGo, (Erişim tarihi: 08.04.2020).

${ }^{65}$ Borisov, ibid, p. 15.
}

\section{1}

Güvenlik Stratejileri

Cilt: 16

Say1: 35 
582

Güvenlik Stratejileri

Cilt: 16

Sayı: 35

Tablo III. Bulgaristan'da Etnik Gruplar İtibarıla 1992, 2001 ve 2011 Nüfus Sayımları ${ }^{66}$

\begin{tabular}{|c|c|c|c|}
\hline Etnik Gruplar & $\mathbf{1 9 9 2}$ & $\mathbf{2 0 0 1}$ & $\mathbf{2 0 1 1}$ \\
\hline Bulgarlar & 7.271 .185 & 6.655 .210 & 5.664 .624 \\
\hline Türkler & 800.052 & 746.664 & 588.318 \\
\hline Romanlar & 313.396 & 370.908 & 325.343 \\
\hline $\begin{array}{c}\text { Diğerleri, Bilinmeyenler } \\
\text { ve Belirtmeyenler }\end{array}$ & 102.684 & 156.119 & 786.285 \\
\hline Toplam & 8.487 .317 & 7.928 .901 & 7.364 .570 \\
\hline
\end{tabular}

Tablo III.'te görüldügü üzere Bulgaristan'da demokrasi tesis edildikten sonra yapılan nüfus sayımlarının her ne kadar güvenilirliğine dair ciddi soru işaretleri olsa da resmî veriler itibarıyla 1992-2011 yılları arasını kapsayan yaklaşık 20 yıllık süre zarfinda hem genel Bulgaristan nüfusunda hem etnik açıdan Bulgar olanların sayısında azalma yaşanmıştır. Ülke genelinde yaklaşık 1,1 milyonluk azalma meydana gelirken, Bulgar nüfusu ise 1,6 milyon civarında düşüş kaydetmiştir. Buna karşın Bulgar olmayanların sayısında artış meydana gelmiştir. 31.12.2019 tarihi itibarıyla Bulgaristan Cumhuriyeti Ulusal İstatistik Enstitüsü (Republika Bllgariya Natsionalen Statistiçeski Institut) verilerine göre ülke nüfusu 6.951 .482 kişi olarak kaydedilmiştir. ${ }^{67}$ Böylece Bulgaristan nüfusunda 1992-2019 arası dönemde \%18 bandında bir azalma yaşandığı görülmektedir. Söz konusu oranın yurtdışına yaşanan yoğun göçler de dikkate alındığında, daha fazla olduğu tahmin edilmektedir. Bu durum ülkede ciddi bir sorun olduğunu işaret ederken Bulgaristan'ın karşılaştı̆̆ı demografi sorununu ifade etmek için "kriz", "felaket" gibi kavramların kullanılmasını beraberinde getirmiştir.

${ }^{66}$ Söz konusu veriler Bulgaristan Ulusal İstatistik Enstitüsü’nden derlenmiştir. Bkz. Republika Bılgariya Natsionalen Statistiçeski İnstitut, http://www.nsi.bg, (Erişim tarihi: 02.04.2020).

${ }^{67}$ Bkz. Republika Bılgariya Natsionalen Statistiçeski İnstitut, "Naselenie po Naselenie Mesta i Pol", https://infostat.nsi.bg/infostat/pages/reports/result.jsf?x_2=1089, (Erişim tarihi: 02.04.2020). 
Nitekim 2011 ve 2018 y1llarındaki her iki Ulusal Güvenlik Stratejisi belgesinde de Bulgar nüfusun azalmasının önlenmesi ve yurtdışına göçlerin azaltılması hususlarına yer verilmiştir. Dolayısıyla Bulgar nüfusunun azalmasının doğrudan bir ulusal güvenlik meselesi haline geldiği görülürken Borisov'un da ifade ettiği bağlam içerisinde Suriyelilerin ülkeye göçleriyle birlikte gelecek dönemlere yönelik nüfus projeksiyonlarında Bulgar çoğunluğun sıralamada yer kaybı ihtimali bulunmaktadır. Farklı bir ifadeyle Bulgar karar alıcılar Suriyeli göçmenler konusunu Waever'ın aktardığ 1 örnek üzerinden ' $X$ halkının Y halkı tarafından istila edilmesi veya o halk yüzünden özelliklerini kaybetmesi”, ${ }^{, 8}$ şeklinde değerlendirdiği anlaşılmaktadır.

Öte yandan ekonomik güvenlik açısından bakıldığında, Bulgaristan ekonomisi üzerinde Suriyeli göçmenlerin katlanılamaz bir maliyet yaratacakları anlaşılmaktadır. Zira Sofya yönetimi, olası bir göçmen akını halinde AB kurumlarının göçmenlerin Batı Avrupa'ya geçişlerine izin vermemesi hususunda kendilerine baskı yapacağını tahmin etmektedir. $\mathrm{Bu}$ nedenle Borisov'un tampon bölge olmayacaklarına yönelik söylemleri anlam kazanmaktadır. ${ }^{69}$ Ayrıca Yunanistan'a ve İtalya'ya tezat olarak göçmenlerin ekonomik maliyetlerini $\mathrm{AB}$ fonları yerine kendi bütçesinden karşılamak zorunda kalması Bulgaristan'ın üzerinde ekonomik güvenlik konusundaki baskı katsayısını artırmaktadır.

Bulgaristan ekonomisinin sahip olduğu yapısal sorunlar da Suriyeli göçmenlerin maliyetlerini karşılamayı güçleştirmektedir. Komünist sistemin çökmesinin ardından serbest piyasa ekonomisine geçiş aşamasında sorunlar yaşayan Bulgaristan, 1994 ve 1996 yıllarında ekonomik krizler yaşamıştır. 1997 yılında yaşanan iktidar değişikliğine bağlı olarak bir taraftan özelleştirme uygulamalarıyla ekonomiyi rahatlatmaya gayret eden diğer taraftan ise Avro-Atlantik kurumlara üyelik sürecini hızlandırmaya çalışan Sofya yönetimi, $\mathrm{AB}$ ile

\footnotetext{
${ }^{68}$ Waever, 2008, ibid, p. 158.

${ }^{69} B N R$, "Boiko Borisov: Nyama da Ostavim Narodite Ni da Stanat Buferna Zona", 24.10.2015, https://bnr.bg/sofia/post/100617075/boiko-borisov-nama-da-ostavim-narodite ni-da-stanat-buferna-zona, (Erişim tarihi: 25.03.2020).
}

\section{3}

Güvenlik Stratejileri

Cilt: 16

Say1: 35 
584

Güvenlik Stratejileri

Cilt: 16

Sayı: 35

müzakerelerinde serbest piyasa ekonomisinin işlevselliğine ilişkin eleştiriler almıştır. Bu eleştirilerin ayrılmaz parçaları olan rüşvet, yolsuzluk ve organize suç örgütleri konusu da Bulgar ekonomisinin yapısal sorunları arasında yer almıştır. ${ }^{70}$ Belirtilen sorunlar 2007'deki $\mathrm{AB}$ üyeliği sonrasında azalma eğiliminde olsa da bunların tamamen ortadan kaldırıldığını ileri sürmek mümkün değildir. Ayrıca nitelikli işgücünün (tıp, mühendislik, teknik personel vb.) $\mathrm{AB}$ üyeliği sonrasında Batı Avrupa ülkelerine göç etmeye başlaması ekonomik gelişimin önünde engel oluşturmuştur. Somut bir örnek vermek gerekirse 2009-2013 yılları arasında Bulgaristan'daki tıp fakültelerinden her yıl 900 hekim mezun olmasına karşın bu dönemde yılda ortalama 1.000 doktorun Batı Avrupa ülkelerine göç ettiği ortaya çıkmıştır. ${ }^{71}$

Suriyeli göçmenlerin Bulgaristan'ın ekonomik güvenliğine tehdit oluşturmasına ilişkin iki temel öncü unsur bulunmaktadır. Birincisi, Cumhurbaşkanı Erdoğan'ın 2 Mart 2020'de Başbakan Borisov ile yaptığı görüşmenin ardından Türkiye'de bulunan Suriyeli göçmenlere yaklaşık 40 milyar \$ harcadıklarını ifade etmesi Bulgar ekonomisi açısından göçmenlerin katlanılamaz bir maliyet oluşturduğu düşüncesini belirginleştirmektedir. Zira Türkiye'nin bu harcaması, 2019 yılı itibarıyla Gayri Safi Yurtiçi Hasılası (GSYH) 66,5 milyar \$ (118,6 milyar Leva) ${ }^{72}$ bandında olan Bulgaristan ekonomisinin yaklaşık 3/5'ine tekabül etmektedir. Diğer bir deyişle Suriyeli göçmenlerin Türkiye'ye olan maliyetinin Bulgaristan açısından ibretlik dersler yarattığı ifade edilebilir. İkincisi ise Suriyeli göçmenlerin aylık ekonomik maliyetlerinin Bulgaristan'daki pek çok kesimin maaşından fazla olmasıdır. Örneğin 2013 ’te bir Suriyeli göçmenin aylık maliyetinin 1.100 Leva olmasına

${ }^{70}$ Özlem, ibid, pp. 191-192.

71 BTV, "1000 Medititsi Godişno Emigrirat ot B1lgariya", 25.11.2013, http://btvnovinite.bg/article/bulgaria/1000-meditsi-godishno-emigrirat-ot-balgariya.html, (Erişim tarihi: 02.04.2020).

${ }_{72}$ Republika Bılgariya Natsionalen Statistiçeski Institut, "Sıobştenie - Bruten Vıreşen Produkt Prez Çetvırtoto Trimeseçie na 2019 G., i prez 2019 Godina, Predvaritelni Danni”, https://www.nsi.bg/sites/default/files/files/pressreleases/GDP2019q4_D2PKTZF.pdf, (Erişim Tarihi: 02.04.2020). 
karşın belirtilen dönemde Bulgaristan'da emekli maaşının 150 Leva, asgari ücretin ise aylık 310 Leva olması kamuoyunda rahatsızlığın ortaya çıkmasına neden olmuştur. ${ }^{73}$ Şubat 2013 döneminde elektrik fiyatlarına yapılan zamlara tepkilerin büyümesi üzerine hükümetin istifa etmek zorunda kaldığ dikkate alındığında, Suriyeli göçmenlerin yaratacağ1 maliyetin sadece ekonomik alanda değil, toplumsal ve siyasal hayatın genel çehresinde radikal sonuçlar yaratacağı anlaşılmaktadır.

$\mathrm{Bu}$ çerçevede Suriyeli göçmenler konusunun siyasi güvenliği de doğrudan tehdit ettiği görülmektedir. Hiç şüphesiz sosyal ve iktisadi yaşamda makro ölçekli sonuçlar doğurması beklenen bir hususun siyasi hayatı etkilemesi de doğaldır. Her ne kadar 2009 sonrası dönemde Bulgaristan siyasetinde Boyko Borisov'un Genel Başkanlığı'ndaki Bulgaristan'ın Avrupai Gelişimi için Vatandaşlar (GERB-Grajdani za Evropeisko Razvitie na Bllgariya) Partisi en önde gelen siyasi yap1 olsa da bu süre zarfında tek başına iktidar olamamış, azınlık hükümetiyle veya koalisyon hükümetleriyle süreci idare etmeye çalışmıştır. Mayıs 2013-Ekim 2014 arasinda Bulgar Sosyalist Partisi (BSP-Bılgarska Sotsialistiçeska Partiya) ve Hak ve Özgürlükler Hareketi (DPSDvijenie za Prava $i$ Svobodi) uzlaşısıyla Plamen Oreşarski'nin başkanlığında hükümetin kurulduğunu belirtmek gerekir. Dolayısıyla Suriyeli göçmen krizinin ulusal bir tehdit olarak algilandığı bu dönemde büyük ölçüde iktidarda bulunan GERB, koalisyon ortaklarıyla uzlaşı sağlamaya gayret etmiştir. Bu durum karar alma süreçlerini kısmen zorlaştırsa da GERB, meseleyi partiler üstü bir platformda ele almaya çalışmış ve bunu da başarmıştır.

Diğer taraftan Bulgar siyasal sisteminin genel yapısı, Suriyeli göçmenler konusunu siyasiler açısından riskli bir alan haline getirmiştir. Genel bir perspektiften meseleye yaklaşıldığında, Bulgaristan'ın demokrasiye geçişinin ardından ülkedeki siyasi durumun istikrarlı bir grafik çizmediği görülmektedir. 1997-2017 yılları arasında herhangi bir siyasi partinin üst üste iki defa hükümeti kuramaması bu durumun

\footnotetext{
${ }^{73}$ Kapital, "Mittt 'Kolko Struva Edin Bejanets", 11 Oktomvri 2013.
} 
586

Güvenlik Stratejileri

Cilt: 16

Sayı: 35 göstergesidir. Sadece GERB 2014 ve 2017 koalisyon hükümetleriyle bunu gerçekleştirmeyi başarmıştır. Dolayısıyla Suriyeli göçmenler konusunun kötü yönetiminin Bulgar siyasal sisteminin istikrarsız yapıs1 içerisinde hükümet değiştirebilme potansiyeline sahip olduğu anlaşılmaktadır. Ayrıca 2005 yılı sonrasında Bulgar siyasal hayatında aşırı milliyetçi, popülist siyasi hareketlerin artış kaydetmesi ve bu kesimin oylarının \%8-10 bandında olması tek başına iktidar olamayan partiler için koalisyon görüşmelerinde dikkate alınmalarını sağlamıştır. Nitekim 26 Mart 2017 Genel Seçimlerinin ardından Borisov hükümeti aşırı milliyetçi Vatanseverler Birliği (OP-Obedinenie Patrioti) ile koalisyon kurmak zorunda kalmıştır.

Saldırgan ve 1rkçı özellikler taşıyan bu partiler siyasal hayatın istikrarı açısından risk teşkil etmiştir. Ne var ki Bulgar siyasal düzeninde bütün partilerin milliyetçi özellikler taşıdığını, bunlar arasında sadece ölçek farklılığının bulunduğunu not etmek gerekir. Yabancı düşmanlığı ve göçmen karşıtlığı gibi popülist söylemleri de benimseyen aşırı milliyetçi partiler için Suriyeli göçmenler konusunun söylem malzemesi oluşturduğu görülmektedir. $\mathrm{Bu}$ durum ana akım partilerin benzer yönelimlerde bulunmalarını tetiklemektedir. Zira seçimle işbaşına gelen karar alıcıların iktidarını sürdürmek isteyecekleri varsayımından hareketle, aşırı milliyetçilere oy kaymalarını önlemek için GERB ve BSP gibi partilerin de göçmen karşıtlığı söylemlerini kullanması kaçınılmaz olmaktadır. Zira yönetilemeyen bir göç akını karşısında siyasi iktidar değişiminin olması muhtemel hale gelirken yeni düzende aşırı milliyetçilerin güçlü bir kamuoyu desteğine sahip olacakları açıktır. Dolayısıyla Suriyeli göçmenler konusunun politik güvenliği de doğrudan tehdit ettiği ileri sürülebilir.

2018 Ulusal Güvenlik Stratejisi Belgesi’nde belirtildiği üzere göç akınının içine sızan yabancı savaşçıların ülkeden geçişlerinin radikalleşme eğilimlerini artırmasının yanı sıra Bulgaristan'da terör hücrelerinin ve lojistik yapılanmalarının ortaya çıkmasına da zemin hazırlayacağı hususu askerî güvenlik açısından tehdit oluşturmaktadır. Gerek Orta Doğu'daki gelişmeler gerek küresel çapta sonuç doğuran terör olayları Bulgar karar alıcıları bu konuda daha temkinli davranmaya itmektedir. Küresel terörün karmaşık yapısının yanında terörle 
Göçün Güvenlikleştirilmesi Bağlamında

Bulgaristan'ın Suriyeli Göçmenlere Yönelik Politikası

mücadelede yeterince tecrübe sahibi olmayan Bulgaristan'ın olası bir göçmen akınına terörist unsurların karışmasıyla büyük bir güvenlik tehdidiyle karşılaşması muhtemeldir. Bu açıdan 2015 y1lı içerisinde Türkiye'nin maruz kaldığı terör saldırıları Bulgaristan açısından önemli dersler içermiştir. Ülke içerisinde zaman zaman terör örgütü DAEŞ ile bağlantılı olduğunu düşündüğü hedeflere yönelik gerçekleştirdiği operasyonlar $^{74}$ Bulgaristan'ın tehdit algilama seviyesini yansitmaktadır. Zira 18 Temmuz 2012'de Bulgaristan'ın Burgaz şehrinde İsrailli turistlerin öldürüldüğü Hizbullah ile bağlantılı terör saldırısında görüldüğü üzere ${ }^{75}$ ülkede terör yapılanmalarının varlığıyla ilgili ortaya çıkan ihtimaller, bu konuyu Bulgar karar alıcıların öncelikli gündem maddeleri arasına dâhil etmiştir.

Öte yandan Bulgaristan'ın Türkiye ile sınırının bulunduğu bölgelerde Bulgar paramiliter unsurlar oluşturularak eğitildiğine ve bu unsurların mülteci avcılığı yaptı̆̆ına ilişkin kamuoyunda haberler yer almıştır. ${ }^{76}$ Aşırı milliyetçi sivil unsurların silahlandırıldığı ve yasadışı göç girişiminde bulunan mültecilerin öldürülmesiyle sonuçlandığı bu sürece Bulgar hükümetinin dâhil olup olmadığ1 soru işaretidir. Ancak söz konusu paramiliter yapıların uzun vadede Bulgaristan'ın güvenliği açısından da tehdit oluşturabileceği görülmektedir.

Vurgulanması gereken bir diğer durumsa olası bir göçmen akınıla Bulgaristan'a salgın hastalıkların taşınması ihtimalinin de ulusal güvenlik açısından risk oluşturacağıdır. Covid-19 Salgını’yla birlikte, uluslararası göçlerin salgın hastalıkları tetiklediğine yönelik

\footnotetext{
${ }^{74} B N T$, “'İslyamska Dirjava’ İma li Kletki u Nas i Kakvo Tryabva da Napravi Bılgariya, za da Bide Sigurna?", 12.12.2014, https://www.bnt.bg/bg/a/islyamska-da-rzhava-ima-likletki-u-nas-i-kakvo-tryabva-da-napravi-ba-lgariya-za-da-ba-de-sigurna, (Erişim tarihi: 02.04.2020); BTV, “Teroristi ot 'İslyamska Dırjava' sa Preminali prez Romskata Mahala na Pazardjik,_https://btvnovinite.bg/bulgaria/teroristi-ot-isljamska-darzhava-sa-preminaliprez-romskata-mahala-na-pazardzhik.html, (Erişim tarihi: 02.04.2020).

${ }^{75}$ Dnes, "Bilgariya Obyavi Ofitsialno: Hizbula Stoi zad Atentata v Burgas", 5 Fevruari 2013.

76 The Sofia Globe, "Concerns Grows over Bulgarian Paramilitaries and Border Patrols", July 7, 2016, https://sofiaglobe.com/2016/07/07/concern-grows-over-bulgarian paramilitaries-and-border-patrols/, (Erişim tarihi: 02.04.2020).
}

587

Güvenlik Stratejileri

Cilt: 16

Say1: 35 
588

Güvenlik Stratejileri

Cilt: 16

Sayı: 35 iddialar Bulgar kamuoyunda hassasiyeti artırırken, bu durumun göçün güvenlikleştirilmesi açısından elverişli bir zemin yarattı̆̆ ifade edilebilir. Ayrıca Bulgar sağlık sisteminin yapısal açıdan zayıf olması, Suriyeli göçmenlerin beraberinde getireceği hastalıkların ulusal güvenlik tehdidi olarak algılanmasını tetiklemektedir.

\section{Sonuç}

Çalışma kapsamında ortaya çıkan bulgularda görüldüğü üzere uluslararası göçler konusu Kopenhag Okulu'nun eleştirel güvenlik yaklaşımında önemli bir yere sahiptir. Waever'in kullandığı güvenlikleştirme kavramı uluslararası göçler konusunda da kendisini göstermektedir. Zira referans nesnesi, siyasal seçkinler ve dinleyiciler denkleminde söylemler aracılığıyla inşa edilen güvenlikleştirme işlemi, tehdidin varlığını sürdürdüğü zaman boyunca işlevselliğini korumaktadır. Soğuk Savaş sonrası dönemde ülkelerin sınır geçirgenliklerinin artmasıyla birlikte uluslararası göçlerin güvenlik tehdidi olarak değerlendirildiği görülmektedir. Bu durum toplumsal, ekonomik, siyasi ve askerî açılardan güvenliğini sağlamak isteyen devletlerin uluslararası göçleri öncelikli hale getirerek güvenlikleştirmeye başvurmalarına yol açmaktadır.

Bir diğer husus ise Suriyeli göçmenler özelinde Bulgaristan'1 tehdit eden kitlesel göçlerin Ulusal Güvenlik Stratejisi Belgeleri'nde net bir şekilde ifade edildiğidir. Bu bağlamda, Suriye İç Savaşı'nın ardından başlayan kitlesel göçler de Bulgaristan'1 yakından ilgilendirmiştir. Zira bu dönemde 3,5 milyona yakın Suriyeli göçmenin Türkiye'de bulunması ve bunların Batı Avrupa ülkelerine yönelik göç girişimleri Sofya yönetiminin ulusal güvenliği açısından risk ve tehditler yaratmıştır. Söz konusu olasılıkların ortadan kaldırılması için güvenlikleştirme yoluna giden Bulgar karar alıcılar, 2013, 2015 ve 2020 yıllarındaki Suriyeli göçmenlerle ilgili gelişmelerde görüleceği üzere aktif bir diplomasi izlemek zorunda kalmıştır. Bu kapsamda Türkiye ile iyi ilişkilerini sürdürmeye çalışan Bulgaristan, çalışmamızda analiz ettiğimiz 18 Mart Mutabakatı sonrasında göreli bir rahatlama dönemi yaşamıştır. 28 Şubat 2020 tarihinde Türkiye'nin göçmenleri engellememe kararı, Bulgaristan nezdinde endişelere yol açsa da Türk tarafının Bulgaristan'a verdiği güvenceyle bu kriz de atlatılmıştır. 
Çalışma kapsamında ortaya çıkan bir diğer bulgu ise Suriyeli göçmenler konusunun Bulgaristan'daki sosyo-ekonomik ve siyasal sistemi doğrudan tehdit ettiği realitesidir. Bulgaristan'ın ulusal kimlik tanımlamasında doğrudan öteki konumunda yer alabilecek olan Suriyeli göçmenlerin, Bulgar karar alıcılar tarafından ülkedeki demografik yapıyı tehdit edebilecekleri düşünülmektedir. Ayrıca bu göçmenlerin beraberinde getireceği ekonomik maliyetlerin de Bulgaristan ekonomisi açısından büyük sorunlar yaratması öngörülmektedir.

Diğer taraftan Ulusal Güvenlik Stratejisi belgelerinde somut bir şekilde tanımlandığı üzere göç akınının içine sızabilecek yabancı savaşçıların askerî açıdan oluşturabileceği tehditler ile Bulgar siyasal sistemi üzerinde makro ölçekli olumsuzluklar yaratma ihtimali Bulgaristan'ın Suriyeli göçmenlere yönelik güvenlik kaygılarını artırmaktadır. Dolayısıyla Suriyeli göçmenler konusu Bulgar devleti tarafindan ulusal güvenlik tehdidi olarak değerlendirilirken, bu tehdit güvenlikleştirme işlemi ve diplomasi aracılığıyla ortadan kaldırılmaya çalışılmıştır.

\section{Summary}

International migration and population movements emerged as an important security issue in the post-Cold War period. The difficulties of the International Relations theories in explaining the issue of migration, have brought new security approaches, as can be seen in the example of the Copenhagen School. Incorporating new concepts such as "security sectors", "securitization" and "social security" into the discipline literature, the Copenhagen School also placed a special emphasis on the issue of international migration. In this context, the securitization of migration has been based upon the persuasion of audiences by political elites through discourses by using of migration theme as a reference object.

The Syrian migrants have a special importance in the scope of international migrations that contributed to the content and extent expansions of security. As known, while the millions of Syrians were leaving their country because of the security concerns after the start of 

Syrian Civil War in 2011, the 3.5 million people of these migrants arrived in Turkey. However, in this process, the migration tendencies of Syrian migrants towards the Western European countries via Turkey have concerned Bulgaria, which is a neighbour country of Turkey, directly. Bulgaria, that has perceived Syrian migrants as a threat for her national security, applied for the securitization process and pro-active diplomacy in order not to be affected negatively from this migration movement.

The international migrations, which were described as a threat in the Bulgaria's National Security Strategy documents, become a primary topic title as seen in the migrant crisis' in the years of 2013, 2015 and 2020. While the Sofia management has succeeded in absorbing the threat of the migration after a successful crisis management, the situation in question cannot be defined as "de-securitization" since the actual threat has not completely disappeared. Essentially, the Syrian migrant crisis for Bulgaria should be evaluated in three periods. The first period between the years of 2011 and 2015 did not include a macro security risk because of low intensity migrations. However, in the second period that could be described as "the crisis period", Bulgaria has come up against a major threat from the flow of migrants toward Bulgaria's border on September 15, 2015 until the date of March 18, 2016, when the EU-Turkey Statement was declared. Bulgaria had a relief phase after the declaration of the Statement. It continued until the decision, that was taken by Turkey on February 28, 2020 regarding not preventing migrants' passing through her borders because of the new migration threat from İdlib, that emerged from the Assad Regime's attacks. This development created a new security threat for Bulgaria. Bulgarian Prime Minister Boyko Borisov re-applied to diplomacy by benefiting from being in good neighbourhood relations with Turkey and having a friendship with Turkish President Recep Tayyip Erdoğan. As a result of these attempts, he succeeded to protect Bulgaria from this migration wave due to Turkey's commitment on the EU-Turkey Statement.

The Syrian migrant issue has threatened the socio-economic and political system directly from the point of Bulgaria. According to Bulgarian decision-makers, Syrians migrants have created a risk for the 
Göçün Güvenlikleştirilmesi Bağlamında

Bulgaristan'ın Suriyeli Göçmenlere Yönelik Politikası

demographic structure in the country as well as other major problems they would bring for the Bulgarian economy. These factors could create radical changes on Bulgarian political system, which has a suitable ground for the rise of ultra-nationalist and racist parties. In addition to this, the foreign fighters, who would infiltrate into migration flow can could generate security threats for Bulgaria from militarily aspect by organizing terrorist structures and their logistic cells as mentioned in the National Security Strategy documents. Consequently, the Syrian migrant issue has been perceived as a threat for national security of Bulgaria in parallel with these factors.

\section{KAYNAKÇA}

\section{Resmî Kaynaklar}

Dirjaven Vestnik (Bulgaristan Devleti Resmî Gazetesi), Broi: 19, 8 Mart 2011.

Dirjaven Vestnik (Bulgaristan Devleti Resmî Gazetesi), Broi: 26, 23 Mart 2018.

Dirjaven Vestnik (Bulgaristan Devleti Resmî Gazetesi), Broi: 46, 22 April 1998.

Dirjavna Agentsiya za Bejantsite pri MS, "Grafiki", http://www.aref.government.bg/sites/ default/files/uploads/docs/2020-03/7\%20-\%20Charts-website-bg_12.pdf, (Erişim tarihi: 25.03.2020).

European Council - Council of the European Union, "EU-Turkey Statement, 18 March 2016", https://www.consilium.europa.eu/en/press/press-releases/2016/03/18/eu-turkeystatement/, (Erişim tarihi: 22.03.2020).

Ministerstvo na Vitreşnite Raboti, Bılgariya i Turtsiya Podpisaha Protokol za Prilagane na Sporazumenieto Mejdu ES i Turtsiya za Readmisiya", 5 Mai 2016, https://www.mvr.bg/ gdgp/начало/преглед/новини/news160505_01, (Erişim tarihi: 23.03.2020).

Narodno Sibranie na Republika Bılgariya, "Zaştitnata Stena po Granitsata s Turtsiya Şte Bıde Gotova v Sıkrateni Srokove Zayavi Ministır-Predsedatelyat Plamen Oreşarski po Vreme na Parlamentarniya Blitskontrol", 06.11.2013, https://parliament.bg/bg/news/ ID/2799, (Erişim tarihi: 24.03.2020).

Official Journal of the European Union, "Regulation (EU) No 604/2013 of the European Parliament and of the Council of 26 June 2013", L 180/31, 29.06.2013, https://eurlex.europa.eu/LexUriServ/LexUriServ.do?uri=OJ:L:2013:180:0031:0059:EN:PDF, (Erişim tarihi: 22.03.2020).

Republika Bılgariya Natsionalen Statistiçeski Institut, "Naselenie po Naselenie Mesta i Pol", https://infostat.nsi.bg/infostat/pages/reports/result.jsf?x_2=1089, (Erişim tarihi: 02.04.2020). 


\section{Kader ÖZLEM}

\section{2}

Güvenlik Stratejileri

Cilt: 16

Sayı: 35

Republika Bılgariya Natsionalen Statistiçeski İnstitut, "Sıobștenie - Bruten Vıreșen Produkt Prez Çetvırtoto Trimeseçie na 2019 G., i prez 2019 Godina, Predvaritelni Danni", https://www.nsi.bg/sites/default/files/files/pressreleases/GDP2019q4_D2PKTZF.pdf, (Erişim Tarihi: 02.04.2020).

Republika Bılgariya Natsionalen Statistiçeski Institut, http://www.nsi.bg, (Erişim tarihi: 02.04.2020).

T.C. Dışş̧̧leri Bakanlı̆̆ı - AB Başkanlığı Resmî İnternet Sayfası, "18 Mart 2016 tarihli Türkiye-AB Zirvesi Bildirisi”, https://www.ab.gov.tr/files/AB_Iliskileri/18_mart_2016_ turkiye_ab_zirvesi_bildirisi_pdf, (Erişim tarihi: 22.03.2020).

Türkiye Cumhuriyeti Resmî Gazete, 02.08.2014, Say1: 29076.

\section{Kitaplar}

BARRY, Buzan and HANSEN, Lene, The Evolution of International Security Studies, Cambridge University Press, Cambridge, 2009.

BARRY, Buzan, People, States, and Fear The National Security Problem in International Relations, Wheatsheaf, Brighton, 1983.

BUZAN, Barry - WAEVER, Ole - WILDE, Jaap de, Security: A New Framework for Anaylsis, Lynne Rienner Publishers, London, 1998.

DİMITROV, Bojidar, 12 Mita v Bılgarskata İstoriya i Mitıt za Batak, Unikart İz., Sofiya, 2015.

DİMITROV, Bojidar, Ístinskata İstoriya na Osvobojdenieto (1860-1878), Standar İz., Sofiya, 2010.

İSOV, Mümün, Nai-Razliçniyat Sised: Obrazıt na Osmantsite (Turtsite) i Osmanskata Imperiya (Turtsiya) v Bılgarskite Uçebnitsi po İstoriya Prez Vtorata Polovina na XX. Vek, Mejdunaroden Tsentır za İzsledvane na Maltsinsvata i Kulturnite Vzaimodeystviya, Sofiya, 2005.

KARABULUT, Bilal, Güvenlik - Küreselleşme Sürecinde Güvenliği Yeniden Düşünmek, Barış Kitabevi, Ankara, 2011.

KARATAY, Osman, Yitik Bir Türk Kavmi Bulgarlar, Ötüken Yayınları, Ankara, 2018. ÖZLEM, Kader, Türkiye-Bulgaristan Illişkileri ve Türk Azınlı, Dora Yayınları, Bursa, 2019.

Makaleler

BORISOV, Boiko, "V Bryuksel Zaştitih Natsionalnite İnteresi", Bejanskata Vilna i Predizvikatelstvata pred Natsionalnata Sigurnost, İnstitut za Strategii i Analizi, Sofiya, 24 Septemvri 2015, ss. 11-15.

MANDACI, Nazif - ÖZERIM, Gökay, "Uluslararası Göçlerin Bir Güvenlik Konusuna Dönüşümü: Avrupa'da Radikal Sağ Partiler ve Göçün Güvenlikleştirilmesi”, Uluslararası İlişkiler, Cilt 10, Sayı 39, Güz 2013, ss. 105-130.

ONUF, Nicholas, "Constructivism: A User's Manuel", International Relations in a Constructed World, (ed. Vendulka Kubalkova-Nicholas Onuf-Paul Kowert, M.E. Sharpe, New York, 1998, ss. 58-78.

ÖZDAL, Barıș ve TUTAN, Esra. “Avrupa Birliği’nin Düzenli Göç Politikası'nın Türkiye'ye Etkileri”. Uluslararası Göç ve Nüfus Hareketleri Bă̆lamında Türkiye, (ed. Barış Özdal), Dora Yayınları, Bursa, 2018, ss. 271-296. 
Göçün Güvenlikleştirilmesi Bağlamında

Bulgaristan'ın Suriyeli Göçmenlere Yönelik Politikası

ÖZDAL, Barış - TUTAN, Esra Vardar, "Suriye'den Türkiye'ye Yönelik Göç Hareketlerinin Türkiye-Avrupa Birliği İlişkilerine Etkilerinin Analizi”, II. Uluslararası Göç ve Mülteci Kongresi Bildirileri: Göç Yönetimi ve Göçmenlerin Entegrasyonunda Başarılı Yönetsel Modeller, 6-7-8 Aralık 2018 - Düzce, ss. 107-127.

REÇBER, Kamuran, "Türkiye Cumhuriyeti Devleti ile Avrupa Birliği Arasında Akdedilen Geri Kabul Anlaşması'nın Yaratabileceği Sonuçların Analizi”, Uluslararası Göç ve Nüfus Hareketleri Bağlamında Türkiye, (ed. Barış Özdal), Dora Yayınları, Bursa, 2018, ss. 297-314.

STRITZEL, Holger, "Towards a Theory of Securitization: Copenhagen and Beyond", European Journal of International Relations, Vol. 13, No. 3, ss. 357-383.

TASHEV, Blagovest, "In Search of Security: Bulgaria's Security Policy in Transition", Papeles del Este, No:8, 2004, ss. 1-20.

WAEVER, Ole, "Toplumsal Güvenliğin Değişen Gündemi”, Uluslararası İlişkiler, Cilt: 5, Say1: 18 (Yaz 2008), ss. 151-178.

WALKER, R.B. J., "Security, Critique and Europe", Security Dialogue, Vol. 38, No. 1, March 2007, ss. 95-103.

WILKINSON, Claire, "The Copenhagen School on Tour in Kyrgyzstan: Is Securitization Theory Useable Outside Europe?", Security Dialogue, Vol. 38, No. 1, March 2007, ss. 5-25. Raporlar, Gazeteler, Haber Ajansları ve İnternet Kaynakları

24Chasa, Siriitsite s Humanitaren Statut Mogat da Ostanat Kolkoto İskat", 27.09.2013. Alpha Research, "Mnozistvo i Maltsinsva: Naglasi kım Razliçnite", https://alpharesearch.bg/api/uploads/Articles\%202020/March\%20-\%20Religions/final_ analyse_results_graphics_31_03_2020.pdf?fbclid=IwAR3ViQ_T6L6MtoPvL6tySvwQA NIpqu3cLLpn1bUUZGV3oWEb2JIPgY3AsGo, (Erişim tarihi: 08.04.2020).

BNT 1, "Borisov: İma Realna Zaplaha ot Bejanska Vılna, Usilili sme Maksimalno Granitsata”, 28.02.2020, https://news.bnt.bg/news/borisov-ima-realna-zaplaha-ot-bezhanska -valna-usilili-sme-maksimalno-granicata-1040665news.html, (Erişim tarihi: 01.04.2020).

BNT 1, "Erdogan Otkaza Sreşta s Liderite ot ES Zaradi Dvama Ubiti Migranti na Granitsata Mejdu Girtsiya i Turtsiya", 02.03.2020, https://news.bnt.bg/news/erdoganotkaza-sreshta-s-liderite-ot-es-zaradi-dvama-ubiti-migranti-na-granicata-mezhdugarciya-i-turciya-1041233news.html, (Erişim tarihi: 01.04.2020).

$B N T$, "'İslyamska Dırjava' İma li Kletki u Nas i Kakvo Tryabva da Napravi Bılgariya, za da Bide Sigurna?", 12.12.2014, https://www.bnt.bg/bg/a/islyamska-da-rzhava-ima-li-kletki-unas-i-kakvo-tryabva-da-napravi-ba-lgariya-za-da-ba-de-sigurna, (Erişim tarihi: 02.04.2020). BTV, "1000 Medititsi Godişno Emigrirat ot Bılgariya", 25.11.2013, http://btvnovinite.bg/article/bulgaria/1000-meditsi-godishno-emigrirat-ot-balgariya.html, (Erişim tarihi: 02.04.2020).

$B N R$, "Boiko Borisov: Nyama da Ostavim Narodite Ni da Stanat Biferna Zona", 24.10.2015, https://bnr.bg/sofia/post/100617075/boiko-borisov-nama-da-ostavim-narodite ni-da-stanat-buferna-zona, (Erişim tarihi: 25.03.2020).

BTV, "Bejanskata Vilna - Zaplaha za Natsionalnata Sigurnost", 7.10.2013, https://btvnovinite.bg/bulgaria/politika/bezhanskata-valna-zaplaha-za-natsionalnatasigurnost-na-balgariya.html, (Erişim tarihi: 25.03.2020). 


\section{Kader ÖZLEM}

594

Güvenlik

Stratejileri

Cilt: 16

Sayı: 35
BTV, "Teroristi ot 'İslyamska Dirjava' sa Preminali prez Romskata Mahala na Pazardjik, https://btvnovinite.bg/bulgaria/teroristi-ot-isljamska-darzhava-sa-preminali-prezromskata-mahala-na-pazardzhik.html, (Erişim tarihi: 02.04.2020).

Defence24, "Bulgaria Updates Its Security Strategy And Suspends Privatization of the Defence Industry", 17 Kwietnia 2016, https://www.defence24.com/bulgaria-updatesits-security-strategy-and-suspends-privatization-of-the-defence-industry, (Erişim tarihi: 20.03.2020).

Deutsche Welle, "Borisov: 'Pomognete B1lgariya!”, 26.08.2016.

Deutsche Welle, "Na B1lgarskata Granitsa e Podozritelno Spokoino. Zaşto?", 02.03.2020.

DHA, "Bulgaristan, Türkiye Sinırındaki Tel Duvarı Uzatıyor", 24.05.2016.

Dnes, "Bilgariya Obyavi Ofitsialno: Hizbula Stoi zad Atentata v Burgas", 5 Fevruari 2013.

Dnes, "Borisov Prati Pozdravi na Erdogan: Blagodariya Ti!", 19 Septemvri 2015.

Dnes, "Borisov Zove da Pomogne na Turtsiya za Migranti", 2 Mart 2020.

Dnes, "Nençev: Ogradata s Turtsiya Şte e Zavirşena v Nai-skoro Vreme", 20 Noemvri 2016.

Duma, "Borisov Şte İska ot Bryuksel da Spre Napadkite kım Turtsiya", 12 Oktomvri 2019.

Duma, "Tryabva da Dadem Otpor na Ksenofobiyata", 23 Noemvri 2013.

Human Rights Watch, "We've Never Seen Such Horror - Crimes against Humanity by Syrian Security Forces", June 2011.

Kapital, "Mitıt 'Kolko Struva Edin Bejanets", 11 Oktomvri 2013.

Nova TV, "Borisov: Otnoşeniyata s Turtsiya sa Vajni Zaradi Migrantite (VIDEO)", 12 Avgust 2016, https://nova.bg/news/view/2016/08/12/156182/борисов-отношениятас-турция-са-важни-заради-мигрантите-видео , (Erişim tarihi: 23.03.2020).

Syrian Observatory for Human Rights, "Syrian Revolution Nine Years on: 586,100 Persons Killed and Millions of Syrians Displaced and Injured", 15.03.2020, http://www.syriahr.com/en/?p=157193, (Erişim tarihi: 18.03.2020).

The Sofia Globe, "Concerns Grows over Bulgarian Paramilitaries and Border Patrols", July 7, 2016, https://sofiaglobe.com/2016/07/07/concern-grows-over-bulgarianparamilitaries-and-border-patrols/, (Erişim tarihi: 02.04.2020).

The UN Refugee Agency, "Syria Regional Refugee Response", https://data2.unhcr.org/ en/situations/syria, (Erişim tarihi: 18.04.2020).

Trud, "Erdogan: 150000 Migranti Trignaha kım Girtsiya, Sled Kato Otvorihme Granitsata", 11.03.2020.

Trud, "Premierıt Boiko Borisov: Nyama Nujda ot Armiya na Granitsata s Turtsiya", 18.09.2015. 